\title{
Crystal structure analysis and supramolecular association in ethyl N- [amino(iminio)methyl] carbamate dichloride hemi-hydrate
}

Christiana Bamigboye, Hanna S Abbo, Huey Chong Kwong, Sang Loon Tan, Edward R.T. Tiekink, Fadhil S Kamounah and Salam J.J. Titinchi

\begin{abstract}
X-ray crystallography on $\left[\mathrm{EtOC}(=\mathrm{O}) \mathrm{N}(\mathrm{H}) \mathrm{C}\left(=\mathrm{N}^{+} \mathrm{H}_{2}\right) \mathrm{NH}_{2}\right] \mathrm{Cl} \cdot 1 \frac{1}{2} \mathrm{H}_{2} \mathrm{O}(\mathbf{1})$ shows the asymmetric unit to comprise two independent cations, two chloride anions and crystal water. The main conformational difference between the cations is seen in the relative orientation of the ethyl groups; geometry-optimisation confirms the all-trans conformation is the most stable. The remaining parts of the cations are co-planar and feature intramolecular $\mathrm{N}-\mathrm{H} \cdots \mathrm{O}$ (carbonyl) hydrogen bonds. An analysis of the $\mathrm{N}-\mathrm{H}$ bonds suggests substantial delocalisation of the positive charge over the $\mathrm{CN}_{3}$ atoms. In the crystal, columns comprising the first independent cation are surrounded by four columns of the second cation within a network of water-O$\mathrm{H} \cdots \mathrm{Cl}, \mathrm{N}-\mathrm{H} \cdots \mathrm{Cl}$ and $\mathrm{N}-\mathrm{H} \cdots \mathrm{O}$ (water, carbonyl) hydrogen bonds, many of which are chargeassisted. The packing has been further investigated by Hirshfeld surface analysis, molecular electrostatic potential and interaction energy calculations. The charge-assisted $\mathrm{N}-\mathrm{H} \cdots \mathrm{Cl}$ hydrogen bonds are significantly stronger than the water- $\mathrm{O}-\mathrm{H} \cdots \mathrm{Cl}$ interactions consistent the distribution of the positive charge over the $\mathrm{CN}_{3}$ atoms.
\end{abstract}

Keywords: Carbamate; computational chemistry, crystal structure analysis; dicyandiamide; Hirshfeld analysis; hydrogen bonding; X-ray diffraction

Running title: bis[diamino((ethoxycarbonyl)amino)methylium] dichloride hemi-hydrate 
*Corresponding author: Salam J.J. Titinchi, Department of Chemistry, University of the Western Cape, Cape Town, South Africa, E-mail: stitinchi@uwc.ac.za

*Corresponding author: Edward R.T. Tiekink, Research Centre for Crystalline Materials, School of Medical and Life Sciences, Sunway University, 47500 Bandar Sunway, Selangor Darul Ehsan, Malaysia, E-mail: edwardt@sunway.edu.my

Christiana Bamigboye, Department of Chemistry, University of the Western Cape, Cape Town, South Africa

Hanna S Abbo, Department of Chemistry, University of the Western Cape, Cape Town, South Africa and Department of Chemistry, College of Science, University of Basrah, Basrah, Iraq Huey Chong Kwong and Sang Loon Tan, Research Centre for Crystalline Materials, School of Medical and Life Sciences, Sunway University, 47500 Bandar Sunway, Selangor Darul Ehsan, Malaysia

Fadhil S Kamounah, Department of Chemistry, University of Copenhagen, Universitetsparken 5, 2100 Copenhagen Ø, Denmark

\section{Introduction}

Herein, the crystal and molecular structures of the ethyl N[amino(iminiumyl)methyl]carbamate cation, as its chloride hemi-hydrate, i.e. $\left[\mathrm{EtOC}(=\mathrm{O}) \mathrm{N}(\mathrm{H}) \mathrm{C}\left(=\mathrm{N}^{+} \mathrm{H}_{2}\right) \mathrm{NH}_{2}\right] \mathrm{Cl}_{1} \frac{1}{2} \mathrm{H}_{2} \mathrm{O}(\mathbf{1})$, is described. While the precursor compound, $\operatorname{EtOC}(=\mathrm{O}) \mathrm{N}(\mathrm{H}) \mathrm{C}(=\mathrm{NH}) \mathrm{NH}_{2}$, was first prepared about 150 years ago $[1,2]$, a search of the literature revealed no definitive evidence for $\mathbf{1}$ although hydrochloride salts have been alluded to since the early 1960's [3]. While the cation in $\mathbf{1}$ has been characterised crystallographically in its 2:1 salt with sulphate in a short note [4], there are no other related cations included in the Cambridge Structural Database [5]. 
Interest in carbamate derivatives, $\mathrm{ROC}(=\mathrm{O}) \mathrm{N}(\mathrm{H}) \mathrm{R}$ ', stems from the isolation in the mid1800 's of the alkaloid, physostigmine, the first reported carbamate compound; this was extracted from the Calabar bean (Physostigma venenosum) found in West Africa [6]. Subsequently, carbamates have received much attention in medicinal chemistry and drug discovery/design, as a result of the presence of hybrid "amide-ester" features and their proteolytic stability, in the polymer industry and for the synthesis of peptides [7-9]. Owing to the ability of carbamates to complex and effectively precipitate metal ions, these have also found use in water treatment [10]. A prototype carbamate is ethyl carbamate, commonly known as urethane. Urethane, a carcinogen, occurs naturally in microgram per litre quantities in fermented food products, such as alcoholic beverages, bread, cheese and yoghurt [11]. On the industrial scale, urethane is produced from the reaction of urea with ethanol [12]. Cyanide compounds also react with alcohols, through the Pinner reaction [13], to form carboxylic esters; the reaction is chemo-selective and mild. The Pinner reaction involves the reaction between an alcohol (either aliphatic or aromatic with no steric hindrance) and a nitrile (either aliphatic or aromatic). Carbonitriles in the presence of hydrochloric acid react with alcohols to give imidate hydrochlorides as reported by Pfaff et al. [14] when they obtained good yields from reacting benzylic carbonitriles with primary alcohol. The reaction mechanism involves activation of nitrilium chloride from protonation of nitrile-nitrogen leading to the alcohol attacking the nitrile carbon [15]. In this study, salt hydrate $\mathbf{1}$ was obtained from the reaction of 1-cyanoguanidine with ethanol in the presence of concentrated hydrochloric acid. The synthesis is complemented by full details of its crystal structure investigated crystallographically and by computational chemistry. 


\section{Experimental}

\section{Materials and instrumentation}

The chemicals were obtained from Sigma Aldrich and used without further purification. The melting point was determined on a Stuart MPS10-120 melting point apparatus using the glass capillary method. The elemental analysis for $\mathrm{C}, \mathrm{H}$ and $\mathrm{N}$ was carried out using a Thermo Flash 1112 Series CHNS-O Analyser. The IR spectrum was recorded using a Perkin Elmer Spectrum Two FT-IR Spectrometer. The NMR data were recorded on a Bruker Avance $400 \mathrm{MHz}$ spectrometer with deuterated water as solvent. Chemical shifts were referenced to residual signal of solvent $\mathrm{D}_{2} \mathrm{O}$.

\section{Synthesis and characterisation}

Concentrated hydrochloric acid ( $0.5 \mathrm{~g})$ was added dropwise to a magnetically stirred solution of 1-cyanoguanidine $(0.4204,0.005 \mathrm{~mol})$ dissolved in absolute ethyl alcohol $(20 \mathrm{ml})$. The reaction was carried out in a one-necked $50 \mathrm{~mL}$ glass round bottomed flask fitted with a water condenser immersed in a thermostated oil bath. The mixture was refluxed for $3 \mathrm{~h}$. At the end of the reaction, the mixture was cooled to room temperature, the solvent removed under reduced pressure and the solid residue recrystallised from ethanol over 3 days to give needleshaped crystals. Yield: $80 \%$, M. pt (crystalline product): 448 K. Elemental analysis: $2\left[\mathrm{C}_{4} \mathrm{H}_{10} \mathrm{~N}_{3} \mathrm{O}_{2}\right] .2 \mathrm{Cl} . \mathrm{H}_{2} \mathrm{O}$. Calcd: C, 27.20; H, 6.28; N, 23.79\%. Found: C, 27.12; H, 6.37; N, 23.68\%. FT-IR; $\mathrm{KBr}\left(\mathrm{cm}^{-1}\right)$ : 3423 to 3100 v( $\mathrm{H}_{2} \mathrm{O}, \mathrm{NH}_{2}$ and $\left.\mathrm{NH}\right) ; 2825$ v(C-H Aliphatic); 1736 $v(\mathrm{C}=\mathrm{O}) ; 1582 v(\mathrm{~N}-\mathrm{H}$, bending $) ; 1272 v(\mathrm{C}-\mathrm{O}) .{ }^{1} \mathrm{H}$ NMR $\left(400 \mathrm{MHz}, \mathrm{D}_{2} \mathrm{O}\right) ; \delta 4.17(\mathrm{q}, 2 \mathrm{H}, J=$ $\left.7.15 \mathrm{~Hz}, \mathrm{CH}_{2}\right), 1.19$ (t, 3H, $\left.J=7.18 \mathrm{~Hz}, \mathrm{CH}_{3}\right)$ ppm; N-H not observed. ${ }^{13} \mathrm{C}$ NMR $(100 \mathrm{MHz}$, $\left.\mathrm{D}_{2} \mathrm{O}\right): \delta 13.2\left(\mathrm{CH}_{3}\right), 63.9\left(\mathrm{CH}_{2}\right), 153.7(\mathrm{C}-\mathrm{N}), 155.0(\mathrm{C}=\mathrm{O}) \mathrm{ppm}$. 


\section{X-ray crystallography}

Intensity data were measured on a colourless prism $(0.10 \times 0.22 \times 0.33 \mathrm{~mm})$ of 1 at $100 \mathrm{~K}$ on a Bruker D8 Venture diffractometer using graphite-monochromatized MoK $\alpha$ radiation $(\lambda=$ $0.71073 \AA$ ). An empirical absorption correction and data processing were accomplished with SAINT [16]. The unit-cell data, X-ray data collection parameters and details of the structure refinement are summarised in Table 1. The structure was solved by Direct Methods using SHELXS [17] and full-matrix least-squares refinement on $\mathrm{F}^{2}$ followed (anisotropic displacement parameters and $\mathrm{C}$-bound $\mathrm{H}$ atoms in their idealised positions) [18]. The $\mathrm{O}-\mathrm{H}$ and $\mathrm{N}-\mathrm{H}$ atoms were located from a difference map and refined with $\mathrm{O}-\mathrm{H}$ and $\mathrm{N}-\mathrm{H}$ distance restraints of $0.84 \pm 0.01$ and $0.88 \pm 0.01 \AA$, respectively. A weighting scheme of the form $w=$ $1 /\left[\sigma^{2}\left(\mathrm{~F}_{\mathrm{o}}^{2}\right)+(\mathrm{aP})^{2}+\mathrm{bP}\right]$ where $\mathrm{P}=\left(\mathrm{Fo}_{\mathrm{o}}^{2}+2 \mathrm{~F}_{\mathrm{c}}^{2}\right) / 3$ was introduced. Towards the end of the refinement, it was determined that the $\mathrm{Cl} 2$ atom was disordered. This was indeed modelled over three sites with the refined site occupancy of the major site being $0.8978(18)$. The site occupancy factors for the minor components were $0.0534(13)$ and $0.0488(17)$; these atoms were refined isotropically. Owing to poor agreement due to the influence of the beam-stop, one low angle reflection, i.e. $\left(\begin{array}{lll}0 & 0 & 1\end{array}\right)$, was removed from the final cycles of refinement. The programs WinGX [19], ORTEP-3 for Windows [19], DIAMOND [20] and PLATON [21], were also used in the analysis.

Tab. 1: Crystallographic data and refinement details for $2\left[\mathrm{C}_{4} \mathrm{H}_{10} \mathrm{~N}_{3} \mathrm{O}_{2}\right] \cdot 2 \mathrm{Cl}_{1} \cdot \mathrm{H}_{2} \mathrm{O}$ (1).

Formula

Formula weight

Crystal system

Space group

$a / \AA$
$\mathrm{C}_{8} \mathrm{H}_{22} \mathrm{Cl}_{2} \mathrm{~N}_{6} \mathrm{O}_{5}$

353.21

triclinic

$P \overline{1}$

4.9756(2) 


\begin{tabular}{|c|c|}
\hline$b / \AA$ & $11.5590(5)$ \\
\hline$c / \AA ̊$ & $14.9966(7)$ \\
\hline$\alpha /^{\circ}$ & $76.210(2)$ \\
\hline$\beta /{ }^{\circ}$ & $80.870(2)$ \\
\hline$\gamma /{ }^{\circ}$ & $78.1720(10)$ \\
\hline$V / \AA^{3}$ & $814.36(6)$ \\
\hline$Z / Z^{\prime}$ & $2 / 1$ \\
\hline$D_{\mathrm{c}} / \mathrm{g} \mathrm{cm}^{-3}$ & 1.440 \\
\hline$F(000)$ & 372 \\
\hline$\mu(\mathrm{MoK \alpha}) / \mathrm{mm}^{-1}$ & 0.428 \\
\hline Measured data & 44057 \\
\hline$\theta$ range ${ }^{\circ}$ & $1.8-30.6$ \\
\hline$\theta \max (100 \%) /^{\circ}$ & 25.2 \\
\hline Unique data & 4985 \\
\hline$R_{\text {int }}$ & 0.044 \\
\hline Observed data $(I \geq 2.0 \sigma(I))$ & 4498 \\
\hline$R$, obs. data; all data & $0.026 ; 0.068$ \\
\hline$a, b$ in weighting scheme & $0.034,0.279$ \\
\hline$R_{\mathrm{w}}$, obs. data; all data & $0.031 ; 0.071$ \\
\hline$\Delta \rho_{\max , \min } / \mathrm{e} \AA^{-3}$ & $0.37,-0.26$ \\
\hline
\end{tabular}

CCDC 2076873 contains the supplementary crystallographic data for this paper. These data can be obtained free of charge via http://www.ccdc.cam.ac.uk/conts/retrieving.html (or from the Cambridge Crystallographic Data Centre, 12, Union Road, Cambridge CB2 1EZ, UK; fax: +44 1223336033$)$. 


\section{Results and discussion}

\section{Synthesis}

Crystals of 1 were isolated in high yield from the reaction of 1-cyanoguanidine with ethanol in the presence of concentrated hydrochloric acid. The likely reaction scheme, i.e. the acidcatalysed reaction of a nitrile derivative with an alcohol to form the alkyl imidate salt, comes under the aegis of the Pinner reaction [13]. The IR shows a sharp peak at $1736 \mathrm{~cm}^{-1}$ corresponding to $v(\mathrm{C}=\mathrm{O})$, and broad absorption bands corresponding to $v\left(\mathrm{H}_{2} \mathrm{O}\right), v\left(\mathrm{NH}_{2}\right)$ and $v(\mathrm{NH})$ in the region 3423 to $3100 \mathrm{~cm}^{-1}$. In the ${ }^{1} \mathrm{H}$ NMR spectrum of 1 recorded in $\mathrm{D}_{2} \mathrm{O}$, the expected resonances for the ethyl protons were observed but not for the N-bound protons owing to exchange with the solvent. The ${ }^{13} \mathrm{C}\left\{{ }^{1} \mathrm{H}\right\}$ NMR show signals at 153.7 and $155.0 \mathrm{ppm}$ which correspond to the $\underline{\mathrm{C}}-\mathrm{N}$ and $\underline{\mathrm{C}}=\mathrm{O}$ nuclei, respectively.

\section{Molecular structure of the cation}

The crystallographic asymmetric unit of 1 comprises two independent cations, shown in Figure 1, two chloride anions and a water molecule of crystallisation. The crystallographic analysis revealed the $\mathrm{Cl} 2$ atom to be disordered over three sites in the ratio 90:5:5. In the ensuing discussion, the minor components of the $\mathrm{Cl} 2$ anion are disregarded.

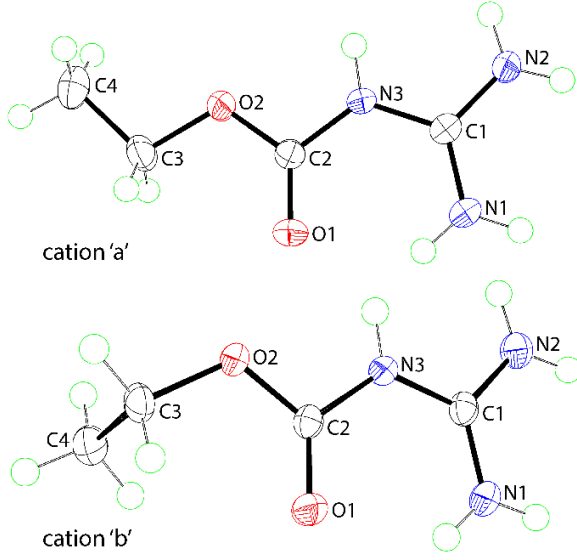


Figure 1. Molecular structures of the two independent cations in $\mathbf{1}$ showing atom labelling scheme and displacement ellipsoids at the $70 \%$ probability level.

The r.m.s. deviation of the seven atoms comprising the $\mathrm{C}_{2} \mathrm{~N}_{3} \mathrm{O}_{2}$ plane in cation a is $0.0173 \AA$ with the maximum deviation being $0.0393(7) \AA$ for the N3a atom; the equivalent parameters for cation $b$ are 0.0271 and $0.0595(7) \AA(\mathrm{N} 3 b)$, respectively. The planarity is consistent with significant delocalisation of the positive charge over the atoms. This is particularly reflected in the near equivalence of the $\mathrm{C} 1-\mathrm{N} 1$ and $\mathrm{C} 1-\mathrm{N} 2$ bond lengths, with the former being marginally shorter for each cation, see Table 2 for data. This suggests a major contribution of canonical form I to the overall electronic structure of the cations in 1, see Figure 2. The $\mathrm{C} 1-\mathrm{N} 3$ bond is also reduced in magnitude from its standard single bond value but not to the same extent as for the $\mathrm{C} 1-\mathrm{N} 1$ and $\mathrm{C} 1-\mathrm{N} 2$ bonds. Thus, canonical form II, Figure 2, with the positive charge distributed over the $\mathrm{CN}_{3}$ atoms, also contributes to the electronic structure. The maximum deviation of a torsion angle from planarity in this part of the cation is seen in the $\mathrm{C} 1-\mathrm{N} 3-\mathrm{C} 2-\mathrm{O} 1$ angle for cation b, i.e. $6.13(15)^{\circ}$. Just as there is a close agreement between chemically equivalent bond lengths in the independent cations, there is also a close concordance in key bond angles, Table 2.

Tab. 2: A comparison of selected geometric parameters $\left(\AA,^{\circ}\right)$ for the experimental cations a and $b$, and the optimised cation.

$\begin{array}{llll}\text { Parameter } & \text { cation a } & \text { cation b } & \text { optimised cation } \\ \mathrm{C} 1-\mathrm{N} 1 & 1.3199(12) & 1.3148(12) & 1.322 \\ \mathrm{C} 1-\mathrm{N} 2 & 1.3227(12) & 1.3259(12) & 1.336 \\ \mathrm{C} 1-\mathrm{N} 3 & 1.3632(12) & 1.3592(11) & 1.359 \\ \mathrm{C} 2-\mathrm{O} 1 & 1.2120(11) & 1.2110(11) & 1.207\end{array}$




\begin{tabular}{|c|c|c|c|}
\hline $\mathrm{C} 2-\mathrm{O} 2$ & $1.3259(11)$ & $1.3270(11)$ & 1.310 \\
\hline $\mathrm{C} 2-\mathrm{N} 3$ & $1.3821(12)$ & $1.3795(12)$ & 1.424 \\
\hline $\mathrm{N} 1-\mathrm{C} 1-\mathrm{N} 2$ & $122.44(9)$ & $122.60(9)$ & 121.5 \\
\hline $\mathrm{N} 1-\mathrm{C} 1-\mathrm{N} 3$ & $121.43(8)$ & 121.89(9) & 120.4 \\
\hline $\mathrm{N} 2-\mathrm{C} 1-\mathrm{N} 3$ & $116.11(8)$ & $115.52(8)$ & 118.1 \\
\hline $\mathrm{O} 1-\mathrm{C} 2-\mathrm{O} 2$ & $125.88(9)$ & $126.52(8)$ & 128.6 \\
\hline $\mathrm{O} 1-\mathrm{C} 2-\mathrm{N} 3$ & $125.19(9)$ & $125.27(8)$ & 122.9 \\
\hline $\mathrm{O} 2-\mathrm{C} 2-\mathrm{N} 3$ & 108.91(8) & $108.20(8)$ & 108.5 \\
\hline $\mathrm{C} 1-\mathrm{N} 3-\mathrm{C} 2-\mathrm{O} 1$ & $5.03(15)$ & $6.13(15)$ & -0.0 \\
\hline $\mathrm{C} 2-\mathrm{O} 2-\mathrm{C} 3-\mathrm{C} 4$ & $176.85(8)$ & $-81.29(10)$ & 179.9 \\
\hline
\end{tabular}

Figure 2. Canonical forms I-III proposed for the cations in $\mathbf{1}$.

The relative orientation of the N1-amine to the carbonyl-O1 enables the formation of an intramolecular amine- $\mathrm{N} 1-\mathrm{H}^{\cdots} \mathrm{O}($ carbonyl) bond to close a $\mathrm{S}(6)$ loop; geometric details are included in Table 3. It is noteworthy that the angles about the $\mathrm{C} 1$ atom subtended by the N1 are significantly wider, by at least $5^{\circ}$, than the angle not involving the $\mathrm{N} 1$ atom. The same observation is evident in the angles about the $\mathrm{C} 2$ atom with those involving the carbonyl-O1 atom being wider by at least $16^{\circ}$ than the angle not involving the $\mathrm{O} 1$ atom; the angles involving 
the two oxygen atoms are the widest by less than $1^{\circ}$ and just over $1^{\circ}$, respectively, indicating no systematic trend.

Tab. 3: Geometric parameters characterising the hydrogen-bonding contacts in the crystal of 1
A $\quad \mathrm{H}$
B
$\mathrm{A}-\mathrm{H}$
$\mathrm{H} \cdots \mathrm{B}$
$\mathrm{A} \cdots \mathrm{B}$
A-H $\cdots$ B Symmetry
operation

$\begin{array}{llllllll}\text { N1a } & \text { H2n } & \text { O1b } & 0.866(11) & 2.063(13) & 2.7029(12) & 130.0(11) \quad x, y, z \\ \text { N1b } & \text { H7n } & \text { O1b } & 0.859(13) & 2.088(14) & 2.7198(11) & 129.9(12) \quad x, y, z \\ \text { N1a } & \text { H1n } & \text { O1w } & 0.873(12) & 2.033(12) & 2.9039(12) & 174.7(14) \quad x, y, z \\ \text { N1a } & \text { H2n } & \text { O1a } & 0.866(11) & 2.257(11) & 2.9751(12) & 140.2(12) & -x, 1-y, 1-z \\ \text { N2a } & \text { H3n } & \text { Cl2 } & 0.866(12) & 2.434(12) & 3.2948(10) & 172.5(14) \quad x, y, z \\ \text { N2a } & \text { H4n } & \text { Cl1 } & 0.863(14) & 2.492(12) & 3.2852(10) & 153.3(12) \quad x, y, z \\ \text { N3a } & \text { H5n } & \text { Cl1 } & 0.872(11) & 2.317(12) & 3.1571(8) & 161.6(11) \quad x, y, z \\ \text { N1b } & \text { H6n } & \text { Cl2 } & 0.868(11) & 2.384(11) & 3.2496(9) & 175.4(13) & -1+x, 1+y, z \\ \text { N1b } & \text { H7n } & \text { O1b } & 0.859(13) & 2.292(14) & 3.0383(12) & 145.3(13) & -x, 2-y,-z \\ \text { N2b } & \text { H8n } & \text { O1w } & 0.873(11) & 2.105(11) & 2.9556(12) & 164.7(14) & x, 1+y, z \\ \text { N2b } & \text { H9n } & \text { Cl1 } & 0.879(12) & 2.499(12) & 3.3052(10) & 152.8(11) \quad x, y, z \\ \text { N3b } & \text { H10n } & \text { Cl1 } & 0.860(11) & 2.308(11) & 3.1468(8) & 165.1(11) \quad x, y, z \\ \text { O1w } & \text { H1o } & \text { Cl2 } & 0.865(12) & 2.192(12) & 3.0499(9) & 171.4(15) \quad-1+x, y, z \\ \text { O1w } & \text { H2o } & \text { Cl2 } & 0.866(12) & 2.159(12) & 3.0219(9) & 174.7(12) \quad x, y, z\end{array}$

With the $\mathrm{C} 1-\mathrm{N} 1$ bond length being marginally shorter than $\mathrm{C} 1-\mathrm{N} 2$, as noted previously, and the pattern of bond angles about the $\mathrm{C} 1$ atom being as just stated, it is concluded there is also a discernible contribution of canonical form III to the electronic structure of $\mathbf{1}$, Figure 2. 
The obvious difference between the cations relates to the relative orientations of the terminal ethyl groups. As seen in the values of the $\mathrm{C} 2-\mathrm{O} 2-\mathrm{C} 3-\mathrm{C} 4$ torsion angles of $176.85(8)$ and $-81.29(10)^{\circ}$, respectively, for cations a and $b$, the ethyl group in cation a is close to coplanar with the rest of the molecule but, in cation b, the ethyl group adopts a - syn-clinal conformation.

The most closely related structure, indeed the only analogue of the cation of $\mathbf{1}$, is noted in the anhydrous sulphate salt where two independent cations comprise the asymmetric unit [4]. The independent cations present similar trends in geometric parameters as noted for 1; the carbon atoms of the terminal ethyl group in each cation is co-planar with the rest of the cation in each case.

The cation in 1 was also subjected to geometry-optimisation calculations in order to assess the influence of the crystalline manifold upon the molecular conformation and geometric parameters; selected data for the optimised structure are included in Table 2. All investigated geometries were subjected to pre-optimisations in the gas phase using Gaussian 16 [22] with the Hartree Fock method [23] and the 3-21G(d) basis set [24] followed by DFT-B3LYP exchange-correlation functional [25] coupled with Pople's 6-311++G( $d, p)$ basis set [26, 27].

The results show that the optimised structure has a similar conformation to that of cation a, rather than cation $\mathrm{b}$, with the torsion angle for $\mathrm{C} 2-\mathrm{O} 2-\mathrm{C} 3-\mathrm{C} 4$ in the optimised cation being $179.90^{\circ}$ compared to $176.85(8)^{\circ}$ and $-81.3(10)^{\circ}$ for cations a and $b$, respectively. These observations are highlighted in Figure 3.

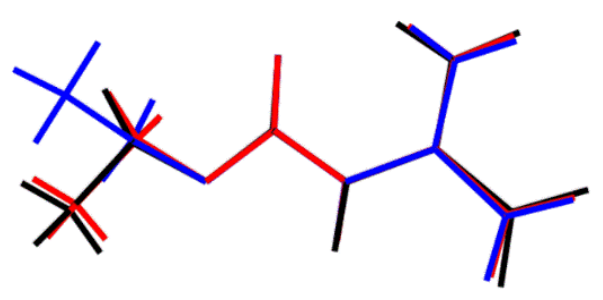


Figure 3. An image showing the superimposition of the experimental structures for cation a (red image), cation b (blue) and the optimised structure (black) overlapped so the N3-C2(O1)$\mathrm{O} 2$ atoms are coincident.

Further to the differences in these torsion angles, the optimised structure also exhibits some additional deviations to the experimentally observed structures. Most notable is the elongation in the $\mathrm{C} 2-\mathrm{N} 3$ bond length in the optimised structure with accompanying shortening of the $\mathrm{C} 2-\mathrm{O} 1$ and $\mathrm{C} 2-\mathrm{O} 2$ bond lengths, and widening and narrowing of the $\mathrm{O} 1-\mathrm{C} 2-\mathrm{O} 2$ and O1-C2-N3 bond angles respectively. These observations are indicative of some charge separation in the $\mathrm{C} 2-\mathrm{N} 3$ bond in the optimised structure. Despite the above, the differences are relatively minor as seen in the root-mean-square deviations of 0.0175 and $0.0183 \AA$ between the bond lengths in the optimised structure and each set of bond lengths for cations a and $b$, respectively. To verify the above, the charge distribution for the optimised structure was assessed by a natural population analysis $[28,29]$, with the results listed as in Table 4 . The analysis reveals the positive charge is predominantly localised on the $\mathrm{C} 1$ atom while all nitrogen atoms clearly carry negative charge, with the amplitude of those negative charges being in the order of $\mathrm{N} 1>\mathrm{N} 2>\mathrm{N} 3$, and that the net charge shift for each of the $\mathrm{C} 1-\mathrm{N} 1, \mathrm{C} 1-$ $\mathrm{N} 2$ and $\mathrm{C} 1-\mathrm{N} 3$ bonds being $1.430,1.419$ and 1.323, respectively. The C2 atom also carries positive charge with the net charge shift for $\mathrm{C} 2-\mathrm{N} 3$ being 1.580 which is evidence that the charge being dispersed in the $\mathrm{C}(=\mathrm{O}) \mathrm{N}(\mathrm{H}) \mathrm{C}\left(=\mathrm{N}^{+} \mathrm{H}_{2}\right) \mathrm{NH}_{2}$ fragment, hence explaining the disparity in the corresponding bonding parameters of the optimised structure.

Tab. 4: Computed NPA charges (e) for non-hydrogen in the optimised structure of cation a Atom NPA charge

O1 $\quad-0.610$ 


$\begin{array}{ll}\mathrm{O} 2 & -0.537 \\ \mathrm{~N} 1 & -0.738 \\ \mathrm{~N} 2 & -0.727 \\ \mathrm{~N} 3 & -0.631 \\ \mathrm{C} 1 & 0.692 \\ \mathrm{C} 2 & 0.949 \\ \mathrm{C} 3 & -0.029 \\ \mathrm{C} 4 & -0.605\end{array}$

A detailed analysis of the natural bonding orbitals (NBOs) shows the hybrid composition for $\mathrm{C} 1-\mathrm{N} 1, \mathrm{C} 1-\mathrm{N} 2, \mathrm{C} 1-\mathrm{N} 3, \mathrm{C} 2-\mathrm{N} 3, \mathrm{C} 2-\mathrm{O} 1$ and $\mathrm{C} 2-\mathrm{O} 2$ bonds comprises about 30.7 to $39.1 \%$ (or $35.0 \%$ on average) $s$-character and 60.7 to $69.2 \%$ (or $67.5 \%$ on average) $p$ character (Table 5) which is close to the composition for ideal $s p^{2}$ hybridisation (ca $33.3 \% s$ and $66.7 \%$-character $)$ rather than $s p^{3}(25.0 \% s$ - and $75.0 \% p$-character; for example for the C3-O2 bond) hybridisation, Figure 4. This analysis confirms the nature of delocalisation of the bonding about the $\mathrm{C} 1$ and $\mathrm{C} 2$ atoms. Complementary to this finding is the natural localised molecular orbital (NLMO) analysis which reveals all the bonding and core orbitals have about $99 \%$ or more electron occupancy except for the lone pair orbitals of O1, O2, N2 and N3 that, correspondingly, display an incomplete occupancy of $91.3-98.6,87.9-97.9,84.2$ and $84.0 \%$, respectively, with the majority of the electron density being localised on the respective lonepair NBOs of those parent atoms while the remnant of the electron density is predominantly found on the adjacent carbon atom, Table 6 . The incomplete occupancy is evidence of electron delocalisation from the lone pairs of $\mathrm{N}$ or $\mathrm{O}$ to the relevant $\mathrm{NBOs}$ of the $\mathrm{C}-\mathrm{O}$ and $\mathrm{C}-\mathrm{N}$, respectively. 


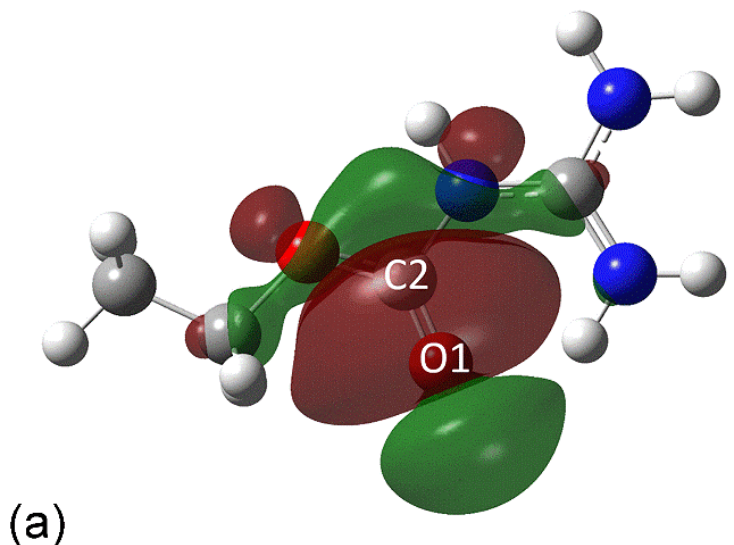

(a)

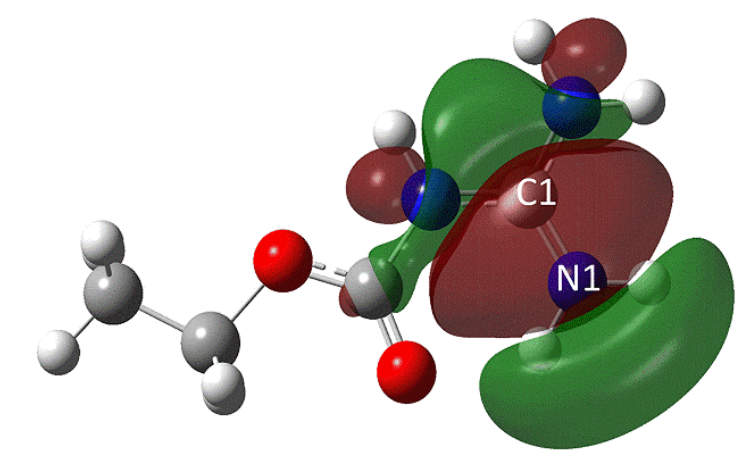

(c)

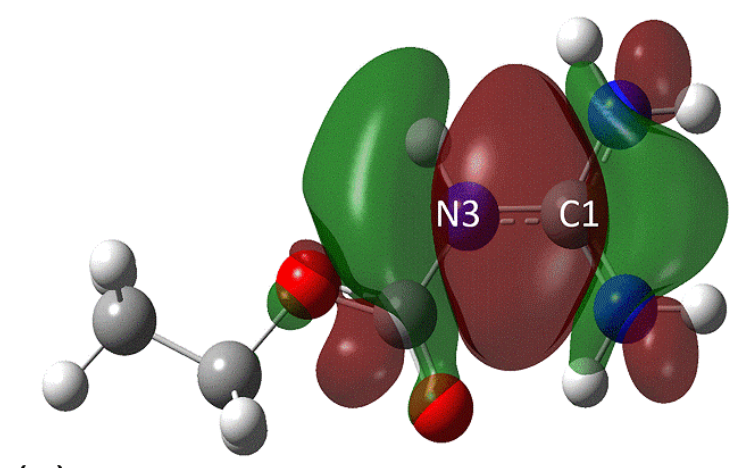

(e)

Figure 4. The natural bonding orbitals at isovalues of 0.004 electron bohr ${ }^{-3}$, showing the hybridisation of the corresponding $s$ and $p$ orbitals for the (a) $\mathrm{C} 2-\mathrm{O} 1$, (b) $\mathrm{C} 2-\mathrm{O} 2$, (c) $\mathrm{C} 1-\mathrm{N} 1$, (d) $\mathrm{C} 1-\mathrm{N} 2$, (e) $\mathrm{C} 1-\mathrm{N} 3$ and (f) $\mathrm{C} 2-\mathrm{N} 3$ bonds.

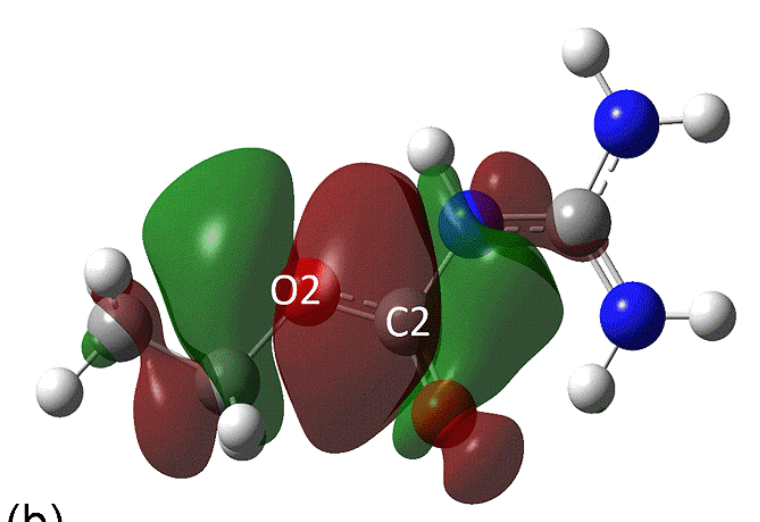

(b)
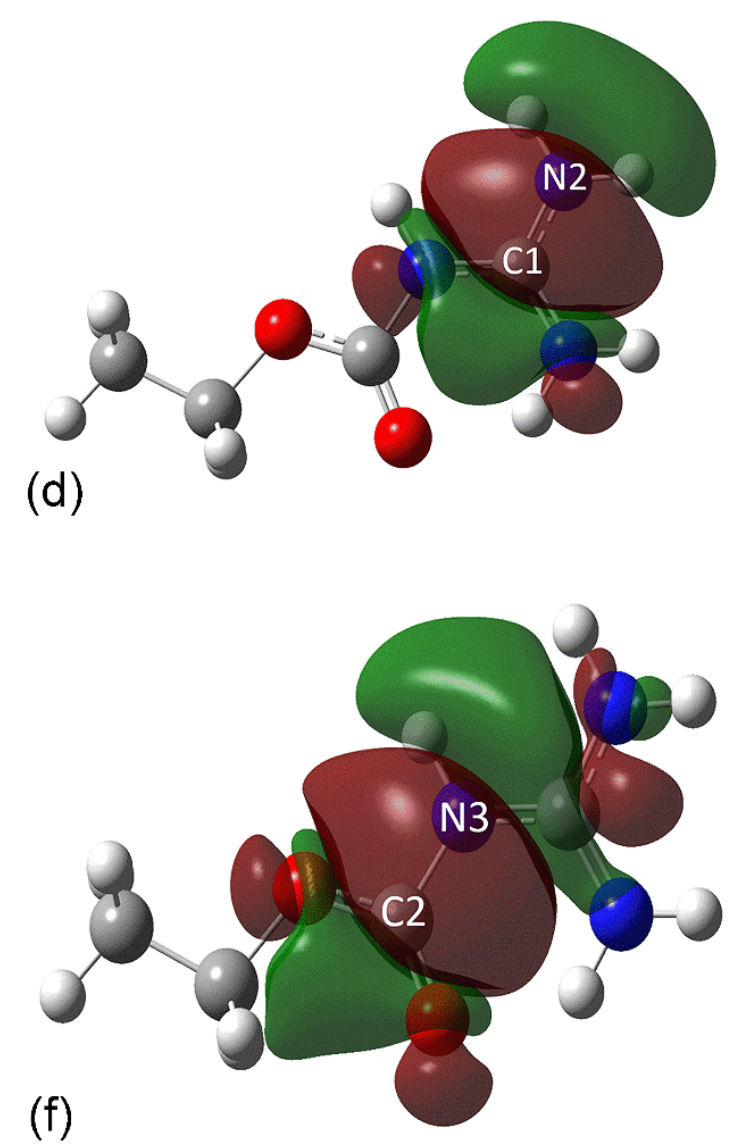

(f) 
Tab. 5: The hybrid composition of selected natural bonding orbitals (NBOs)

\begin{tabular}{|c|c|c|c|c|c|c|}
\hline \multirow[t]{2}{*}{$C \cdots X$} & \multicolumn{3}{|c|}{$\mathrm{C}$} & \multicolumn{3}{|c|}{$X$} \\
\hline & $\begin{array}{l}\text { Overall } \\
\text { occupancy } \\
\%\end{array}$ & $\%$ & $\%$ & $\begin{array}{l}\text { Overall } \\
\text { occupancy } \\
\%\end{array}$ & $\%$ & $\%$ \\
\hline $\mathrm{C} 1-\mathrm{N} 1$ & 41.3 & 34.4 & 65.5 & 58.7 & 37.7 & 62.3 \\
\hline $\mathrm{C} 1-\mathrm{N} 2$ & 41.0 & 33.3 & 66.7 & 59.0 & 39.1 & 60.8 \\
\hline $\mathrm{C} 1-\mathrm{N} 3$ & 39.7 & 32.3 & 67.6 & 60.3 & 37.0 & 62.9 \\
\hline $\mathrm{C} 2-\mathrm{N} 3$ & 35.9 & 30.7 & 69.2 & 64.1 & 34.3 & 65.6 \\
\hline $\mathrm{C} 2-\mathrm{O} 1$ & 35.7 & 37.1 & 62.8 & 64.3 & 39.1 & 60.7 \\
\hline $\mathrm{C} 2-\mathrm{O} 2$ & 33.0 & 32.1 & 67.6 & 67.0 & 32.4 & 67.5 \\
\hline $\mathrm{C} 3-\mathrm{O} 2$ & 27.9 & 17.4 & 82.3 & 72.1 & 28.7 & 71.3 \\
\hline
\end{tabular}

Tab. 6: The composition of selected natural localised molecular orbital (NLMOs) and decomposed Natural Atomic Orbital (NAOs), showing the percentage of the NLMO on each non-H atom and hybrid composition ratios of the NAOs

\begin{tabular}{|c|c|c|c|c|c|}
\hline \multirow[t]{2}{*}{ Parent orbital } & \multirow[t]{2}{*}{$\%$ Occupancy } & \multicolumn{2}{|c|}{ Decomposed } & \multicolumn{2}{|c|}{$\%$ Composition ratio $s: p: d$} \\
\hline & & NAO & $s$ & $p$ & $d$ \\
\hline \multirow[t]{7}{*}{$\mathrm{LP}(1) \mathrm{O} 1$} & 98.6 & O1 & 60.8 & 39.2 & 0.0 \\
\hline & 0.0 & $\mathrm{O} 2$ & 14.5 & 85.3 & 0.2 \\
\hline & 0.1 & N1 & 45.3 & 54.6 & 0.1 \\
\hline & 0.1 & N3 & 41.7 & 57.7 & 0.7 \\
\hline & 0.0 & $\mathrm{C} 1$ & 11.1 & 88.5 & 0.4 \\
\hline & 0.8 & $\mathrm{C} 2$ & 17.2 & 82.7 & 0.1 \\
\hline & 0.0 & C3 & 3.6 & 96.1 & 0.3 \\
\hline
\end{tabular}




\begin{tabular}{|c|c|c|c|c|c|}
\hline \multirow[t]{7}{*}{$\mathrm{LP}(2) \mathrm{O} 1$} & 91.3 & $\mathrm{O} 1$ & 0.1 & 99.8 & 0.1 \\
\hline & 1.2 & $\mathrm{O} 2$ & 41.9 & 57.7 & 0.4 \\
\hline & 0.2 & N1 & 41.2 & 58.5 & 0.3 \\
\hline & 1.3 & N3 & 43.4 & 56.2 & 0.4 \\
\hline & 0.0 & $\mathrm{C} 1$ & 30.7 & 68.9 & 0.4 \\
\hline & 5.1 & $\mathrm{C} 2$ & 0.2 & 99.8 & 0.1 \\
\hline & 0.1 & $\mathrm{C} 3$ & 9.2 & 90.0 & 0.8 \\
\hline \multirow[t]{6}{*}{$\mathrm{LP}(1) \mathrm{O} 2$} & 97.9 & $\mathrm{O} 2$ & 38.8 & 61.2 & 0.0 \\
\hline & 0.3 & $\mathrm{O} 1$ & 44.4 & 54.8 & 0.9 \\
\hline & 0.2 & N3 & 53.5 & 45.5 & 1.1 \\
\hline & 0.1 & $\mathrm{C} 1$ & 34.6 & 65.2 & 0.2 \\
\hline & 1.1 & $\mathrm{C} 2$ & 4.8 & 91. & 4.2 \\
\hline & 0.2 & $\mathrm{C} 3$ & 15.8 & 74.1 & 10.2 \\
\hline \multirow[t]{8}{*}{$\mathrm{LP}(2) \mathrm{O} 2$} & 87.9 & $\mathrm{O} 2$ & 0.0 & 99.9 & 0.1 \\
\hline & 3.2 & $\mathrm{O} 1$ & 0.0 & 99.9 & 0.1 \\
\hline & 0.0 & N3 & 0.0 & 99.3 & 0.7 \\
\hline & 0.0 & N4 & 0.0 & 99.8 & 0.2 \\
\hline & 0.0 & N5 & 0.0 & 99.8 & 0.2 \\
\hline & 0.1 & $\mathrm{C} 6$ & 0.0 & 99.9 & 0.1 \\
\hline & 8.1 & $\mathrm{C} 7$ & 0.0 & 99.9 & 0.1 \\
\hline & 0.3 & $\mathrm{C} 8$ & 0.0 & 99.9 & 0.1 \\
\hline
\end{tabular}




\begin{tabular}{|c|c|c|c|c|c|}
\hline \multirow[t]{6}{*}{$\mathrm{LP}(1) \mathrm{N} 2$} & 84.2 & N2 & 0.0 & 100.0 & 0.0 \\
\hline & 0.0 & O1 & 0.0 & 99.7 & 0.3 \\
\hline & 3.5 & N1 & 0.0 & 100.0 & 0.0 \\
\hline & 0.0 & N3 & 0.0 & 99.6 & 0.4 \\
\hline & 12.2 & $\mathrm{C} 1$ & 0.0 & 99.9 & 0.1 \\
\hline & 0.1 & $\mathrm{C} 2$ & 0.0 & 100.0 & 0.0 \\
\hline \multirow[t]{7}{*}{$\mathrm{LP}(1) \mathrm{N} 3$} & 84.0 & N3 & 0.0 & 100.0 & 0.0 \\
\hline & 1.3 & $\mathrm{O} 1$ & 0.0 & 99.9 & 0.1 \\
\hline & 0.6 & $\mathrm{O} 2$ & 0.0 & 99.8 & 0.2 \\
\hline & 2.0 & N1 & 0.0 & 99.9 & 0.1 \\
\hline & 1.7 & $\mathrm{~N} 2$ & 0.0 & 99.9 & 0.1 \\
\hline & 7.0 & $\mathrm{C} 1$ & 0.0 & 99.6 & 0.4 \\
\hline & 3.5 & $\mathrm{C} 2$ & 0.0 & 99.9 & 0.1 \\
\hline
\end{tabular}

Owing to the difference in geometry for the ethyl group noted between cations a and $b$, the molecular structure was subjected to a relaxed potential energy scan upon systematic rotation about the $\mathrm{C} 2-\mathrm{O} 2-\mathrm{C} 3-\mathrm{C} 4$ torsion angle by $\mathrm{B} 3 \mathrm{LYP} / 6-311+\mathrm{G}(d, p)$ in order to assess the effect on the variation of the torsion angle over the potential energy surface. Through the energy profile shown in Figure 5, it is evident the cation has the lowest energy at torsion angles of about $180^{\circ}$ (as noted in experimental cation a) and the energy gradually increased to peak at approximately $0^{\circ}$ due to steric hindrance. At torsion angles of about $-80^{\circ}$, the rotamer (as noted for cation b) exhibits a relative energy of $0.331 \mathrm{kcal} / \mathrm{mol}$ less stable than the optimised cation. A vibrational analysis confirms that the cation $b$ occurs at a local minimum with no imaginary frequency. 


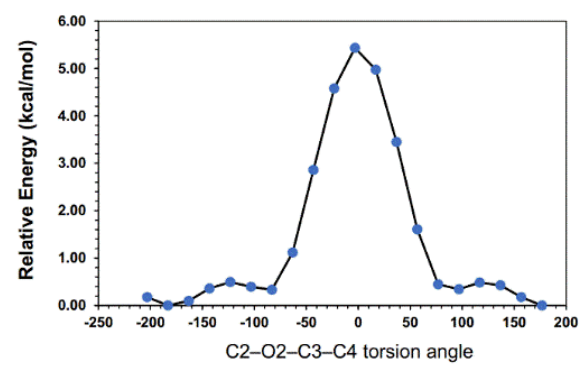

Figure 5. Potential energy profile upon incremental rotation about the $\mathrm{C} 2-\mathrm{O} 2-\mathrm{C} 3-\mathrm{C} 4$ torsion angle of the cation.

\section{Molecular packing}

As anticipated from the chemical composition of $\mathbf{1}$, there are a large number of conventional hydrogen bonds present in the crystal which combine to stabilise a three-dimensional architecture; the geometric parameters for the interactions are collected in Table 3 . The hydrogen bonds involving the chloride anions are clearly charge-assisted and it is likely there is additional charge-assistance in the hydrogen bonds involving the N-bound protons, especially those bound to N1- and N2. In the following analysis, the contribution of the minor components of the disordered $\mathrm{Cl} 2$ anion are ignored. As noted above, one of the amine-N1-H atoms participates in an intramolecular hydrogen bond. For each cation, the same hydrogen atom is bifurcated, also forming an amine- $\mathrm{N}-\mathrm{H} \cdots \mathrm{O}$ (carbonyl) hydrogen bond with a symmetry related carbonyl group derived from the same cation. For cation a, the second amine-H atom forms a $\mathrm{N}-\mathrm{H} \cdots \mathrm{O}$ (water) hydrogen bond whereas for cation $\mathrm{b}$, the hydrogen bond is to a $\mathrm{Cl} 2$ atom. For the amine-N2-H atom syn with the aforementioned hydrogen atoms, the hydrogen bonding is opposite, i.e. for cation a, $\mathrm{N}-\mathrm{H} \cdots \mathrm{Cl}$ and for cation $\mathrm{b}, \mathrm{N}-\mathrm{H} \cdots \mathrm{O}$ (water). The four remaining acidic hydrogen atoms form $\mathrm{N}-\mathrm{H} \cdots \mathrm{Cl}$ hydrogen bonds to the same $\mathrm{Cl1}$ anion. From the above description, the water molecule accepts two amine- $\mathrm{N}-\mathrm{H} \cdots \mathrm{O}($ water) hydrogen bonds. This molecule also participates in two water- $\mathrm{O}-\mathrm{H} \cdots \mathrm{Cl}$ hydrogen bonds. The $\mathrm{Cl} 1$ anion accepts four amine- $\mathrm{N}-\mathrm{H} \cdots \mathrm{O}$ hydrogen bonds whereas the $\mathrm{Cl} 2$ anion accepts two amine- $\mathrm{N}-\mathrm{H} \cdots \mathrm{O}$ and 
two water-O- $\mathrm{H} \cdots \mathrm{Cl}$ hydrogen bonds. A view of the unit-cell contents is given in Figure 6. Globally, the columns comprising cation a, located in the centre of Figure 6, are surrounded by four columns comprising cations $b$. The connections between columns are either through amine- $\mathrm{N}-\mathrm{H} \cdots \mathrm{Cl}$ hydrogen bonds or a combination of amine- $\mathrm{N}-\mathrm{H} \cdots \mathrm{Cl}$ and amine-N$\mathrm{H} \cdots \mathrm{O}$ (water) hydrogen bonds.

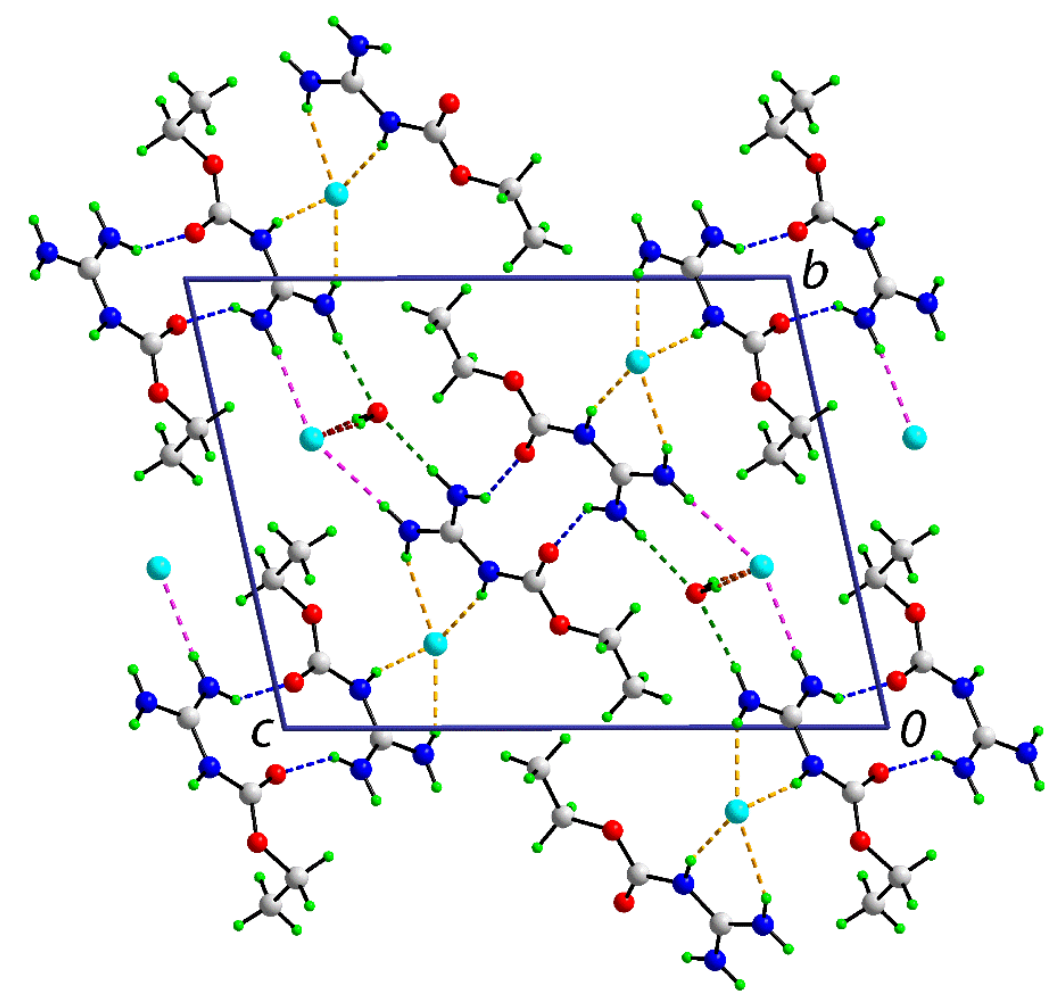

Figure 6. A view of the unit-cell contents for $\mathbf{1}$ in projection down the a-axis. The $\mathrm{N}-$ $\mathrm{H}^{\cdots} \mathrm{O}($ carbonyl), $\mathrm{N}-\mathrm{H} \cdots \mathrm{Cl} 1, \mathrm{~N}-\mathrm{H} \cdots \mathrm{Cl} 2, \mathrm{~N}-\mathrm{H} \cdots \mathrm{O}($ water) and water-O$-\mathrm{H} \cdots \mathrm{Cl} 2$ hydrogen bonds are shown as blue, orange, pink, green and brown dashed lines, respectively.

The Hirshfeld surface analysis for each constituent of $\mathbf{1}$ was conducted to provide further information on the supramolecular connections in the crystal to complement the pointto-point analysis conducted with the aid of PLATON [21] and to identify other intermolecular contacts not highlighted thus far. The calculated Hirshfeld surface was mapped over the normalised contact distance $d_{\text {norm }}[30]$ with associated two-dimensional fingerprint plots [31] 
using the CrystalExplorer 17.5 program [32] following established procedures [33]. The $\mathrm{d}_{\text {norm- }}$ plots were mapped with high surface resolution by applying TONTO [34] calculation and colour scaled in the range -0.491 (blue) and 1.184 (red) arbitrary units.

As a bifurcated acceptor and donor, the four red spots on the $\mathrm{d}_{\text {norm-Hirshfeld surface of }}$ the water molecule are due to the formation of conventional amine- $\mathrm{N}-\mathrm{H} \cdots \mathrm{O}$ (water) and water$\mathrm{O}-\mathrm{H} \cdots \mathrm{Cl} 2$ hydrogen bonds as shown in Figure 7.

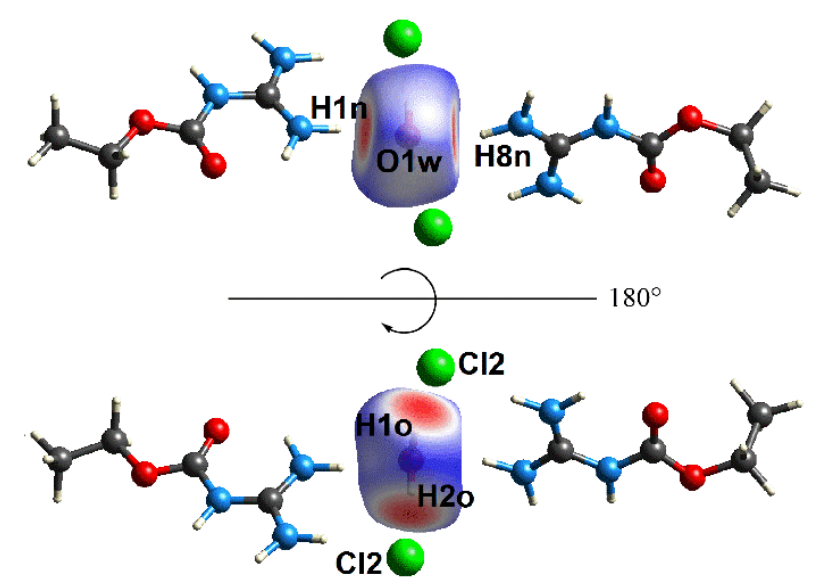

Figure 7. A view of the dnorm-Hirshfeld surface for the water molecule in $\mathbf{1}$, highlighting the influence of $\mathrm{N}-\mathrm{H} \cdots \mathrm{O}$ (water) and water-O- $\mathrm{H}^{\cdots} \mathrm{Cl} 2$ hydrogen bonds.

For the $\mathrm{Cl1}$ anion, the red spots observed on the Hirshfeld surface mapped over $\mathrm{d}_{\text {norm }}$ shown in Figure $8 \mathrm{a}$, arise as a result of the conventional amine- $\mathrm{N}-\mathrm{H} \cdots \mathrm{Cl1}$ hydrogen bonds. Whereas the red spots apparent about the $\mathrm{Cl} 2$ anion are the result of amine- $\mathrm{N}-\mathrm{H} \cdots \mathrm{Cl} 2$ and water- $\mathrm{O}-\mathrm{H} \cdots \mathrm{Cl} 2$ hydrogen bonds, as highlighted in Figure $8 \mathrm{~b}$. 
(a)

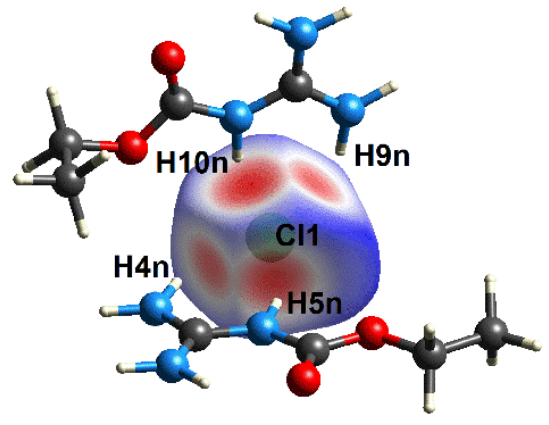

(b)

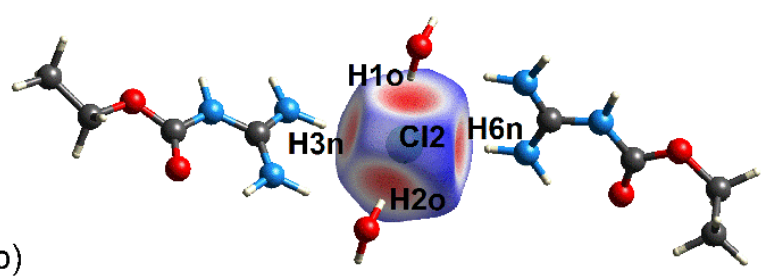

Figure 8. A view of the $\mathrm{d}_{\text {norm}}$-Hirshfeld surface about the chloride anions in the crystal of $\mathbf{1}$ :

(a) for the $\mathrm{Cl} 1$ anion, highlighting $\mathrm{N}-\mathrm{H} \cdots \mathrm{Cl} 1$ hydrogen bonds and (b) for the $\mathrm{Cl} 2$ anion, highlighting $\mathrm{O} / \mathrm{N}-\mathrm{H} \cdots \mathrm{Cl} 2$ hydrogen bonds.

In both cations, the bright red spots near the amine- $\mathrm{N}-\mathrm{H}$ atoms correspond to the conventional hydrogen bonds they form. The amine- $\mathrm{N}-\mathrm{H} \cdots \mathrm{O}($ carbonyl) and amine-N$\mathrm{H} \cdots \mathrm{Cll}$ hydrogen bonds appear at approximately the same positions for both cations as highlighted in the left-hand images of Figure 9. In the same way, the spots due to interactions involving the $\mathrm{Cl} 1$ anions appear in similar positions. By contrast, the spots due to the amine$\mathrm{N}-\mathrm{H} \cdots \mathrm{Cl} 2$ and amine- $\mathrm{N}-\mathrm{H} \cdots \mathrm{O}$ (water) hydrogen bonds appear at opposite positions for cation a compared with cation $b$. 
(a)
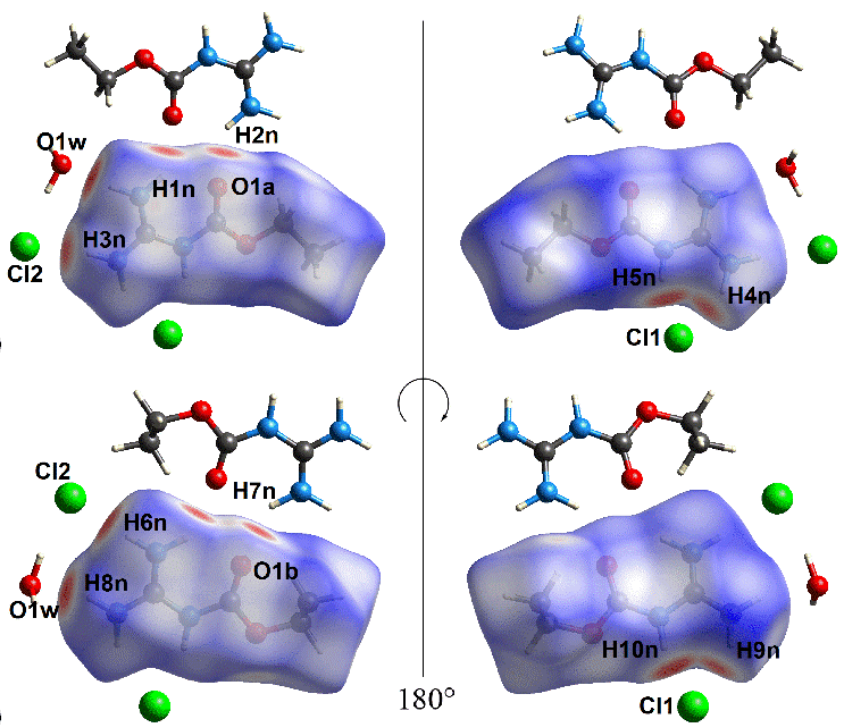

(b)

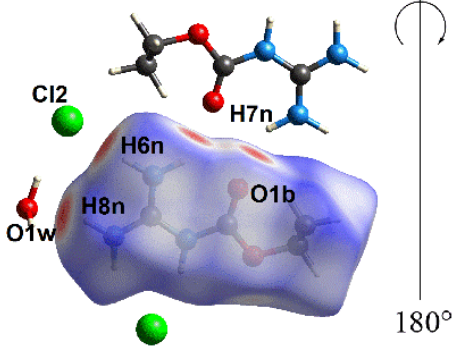

Figure 9. Views of the dnorm-Hirshfeld surfaces for the cations in the crystal of 1: (a) cation a and (b) cation $b$.

The other major differences between two cations is the appearance of faint red spots near the N1a, O1a and $\mathrm{O} 2 \mathrm{~b}$ atoms. These correlate with the weak $\pi \cdots \pi$ stacking between two imine groups derived from symmetry related cations of a, as shown in Figure 10a, and the weak methyl-C4-H $\cdots \mathrm{O} 2$ contact involving cations of b, Figure 10b. Geometric details for these interactions are given in Table 7. 


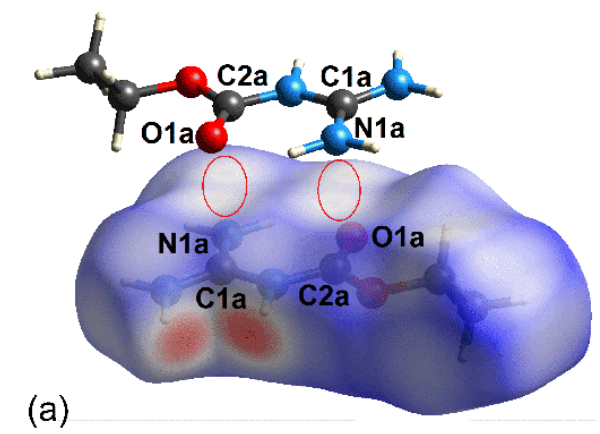

(a)

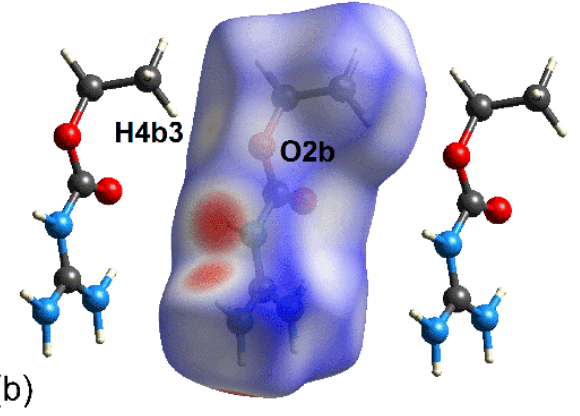

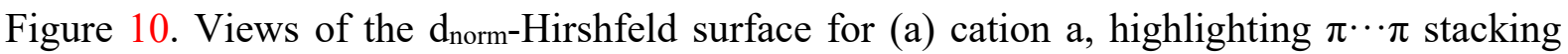
between two imine groups and (b) cation b, highlighting the methyl-C4-H $\cdots \mathrm{O} 2$ contact.

Tab. 7: Summary of short interatomic contacts $(\AA)$ identified in the Hirshfeld surface analysis of $1 .^{\mathrm{a}}$

$\begin{array}{lll}\text { Contact } & \text { Distance } & \text { Symmetry operation } \\ \mathrm{N} 1 \mathrm{a} \cdots \mathrm{C} 2 \mathrm{a} & 3.21 & -x+1,-y+1,-z+1 \\ \mathrm{C} 1 \mathrm{a} \cdots \mathrm{O} 1 \mathrm{a} & 3.19 & -x+1,-y+1,-z+1 \\ \mathrm{C} 4 \mathrm{~b}-\mathrm{H} 4 \mathrm{~b} 3 \cdots \mathrm{O} 2 \mathrm{~b} & 2.53 & x-1, y, z\end{array}$

$a$ : The interatomic distances are measured in Crystal Explorer 17 whereby the $\mathrm{X}-\mathrm{H}$ bond lengths are adjusted to their neutron values.

Two-dimensional fingerprint plots were generated in order to quantify the interatomic contacts for each individual species: water, $\mathrm{Cl} 1$ and $\mathrm{Cl} 2$ anions, and cations a and $\mathrm{b}$. The overall fingerprint plot and those delineated into $\mathrm{H} \cdots \mathrm{H}, \mathrm{H} \cdots \mathrm{O} / \mathrm{O} \cdots \mathrm{H}, \mathrm{H} \cdots \mathrm{Cl} / \mathrm{Cl} \cdots \mathrm{H}, \mathrm{H} \cdots \mathrm{N} / \mathrm{N} \cdots \mathrm{H}$ and 
$\mathrm{C} \cdots \mathrm{Cl} / \mathrm{Cl} \cdots \mathrm{C}$ surface contacts are illustrated in Figure 11, and Table 8 collates the percentage contributions of the delineated contacts.
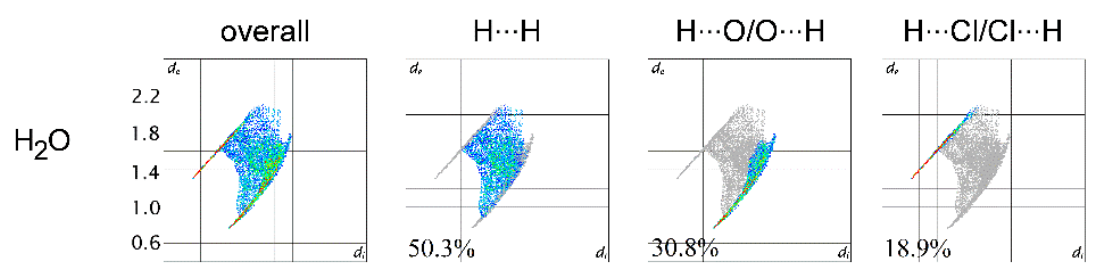

$H \cdots N / N \cdots H$

$\mathrm{C} \cdots \mathrm{Cl} / \mathrm{Cl} \cdots \mathrm{C}$
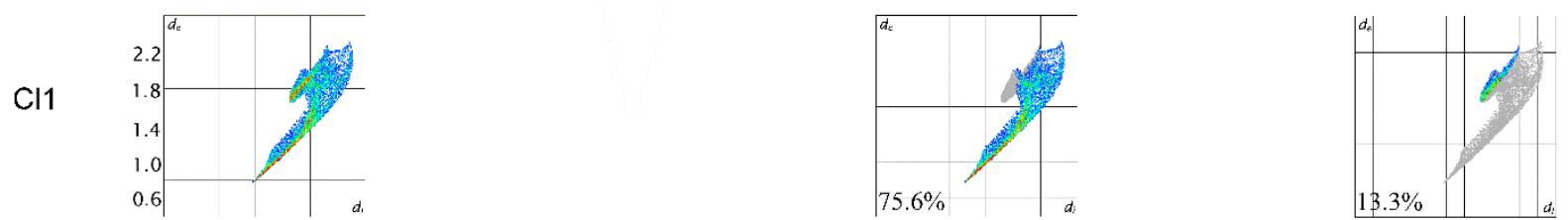

$\mathrm{Cl} 2$
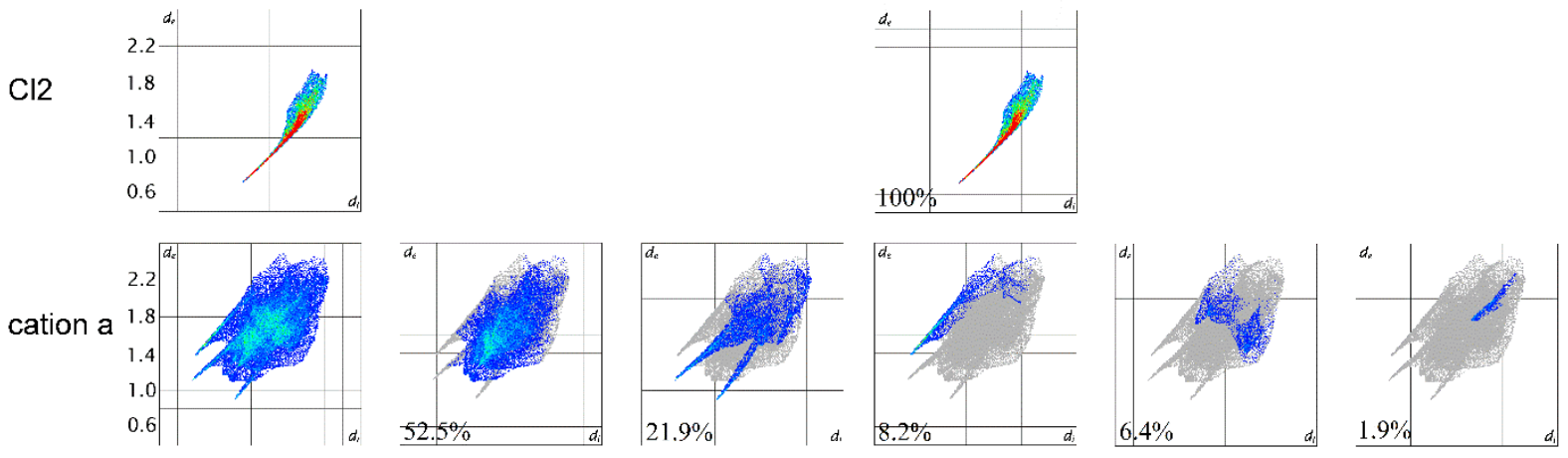

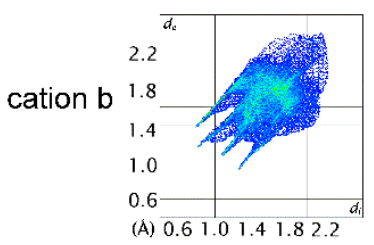

(a)

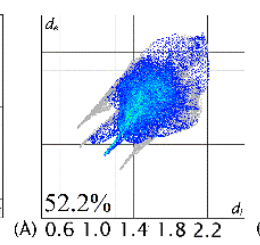

(b)

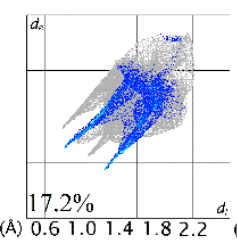

(c)

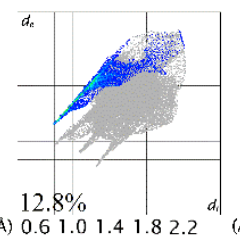

(d)

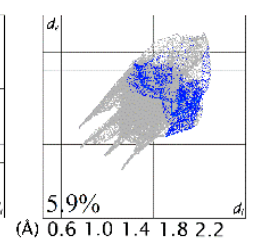

(e)

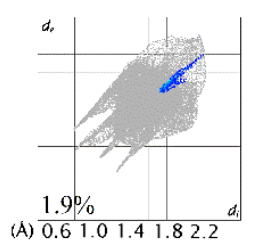

(f)

Figure 11. (a) Overall two-dimensional fingerprint plots for the water molecule, $\mathrm{Cl1}$ and $\mathrm{Cl} 2$ anions, and cations a and $b$, and those delineated into (b) $\mathrm{H} \cdots \mathrm{H}$, (c) $\mathrm{H} \cdots \mathrm{O} / \mathrm{O} \cdots \mathrm{H}$, (d) $\mathrm{H} \cdots \mathrm{Cl} / \mathrm{Cl} \cdots \mathrm{H}$, (e) $\mathrm{H} \cdots \mathrm{N} / \mathrm{N} \cdots \mathrm{H}$ and (f) $\mathrm{C} \cdots \mathrm{Cl} / \mathrm{Cl} \cdots \mathrm{C}$ contacts.

Although the water molecule participated in strong $\mathrm{N}-\mathrm{H} \cdots \mathrm{O}$ and $\mathrm{O}-\mathrm{H} \cdots \mathrm{O}$ hydrogen bonds, the major surface contacts contributing to its overall Hirshfeld surface are $\mathrm{H} \cdots \mathrm{H}$ contacts $(50.3 \%)$ with $\mathrm{de}_{\mathrm{e}}+\mathrm{d}_{\mathrm{i}} \sim 2.1 \AA$, with $\mathrm{H} \cdots \mathrm{O} / \mathrm{O} \cdots \mathrm{H}$ and $\mathrm{H} \cdots \mathrm{Cl} / \mathrm{Cl} \cdots \mathrm{H}$ contacts contributing 30.8 and $18.9 \%$, respectively, to the Hirshfeld surface. 
It is clear the $\mathrm{N}-\mathrm{H} \cdots \mathrm{Cl} 1$ hydrogen bonds occurred to one side of the $\mathrm{Cl} 1$ anion so the $\mathrm{H} \cdots \mathrm{Cl} / \mathrm{Cl} \cdots \mathrm{H}$ contacts only contributed $75.6 \%$ to its overall Hirshfeld surface, with the rest of the surface due to $\mathrm{C} \cdots \mathrm{Cl} / \mathrm{Cl} \cdots \mathrm{C}(13.3 \%), \mathrm{N} \cdots \mathrm{Cl} / \mathrm{Cl} \cdots \mathrm{N}(7.3 \%)$ and $\mathrm{O} \cdots \mathrm{Cl} / \mathrm{Cl} \cdots \mathrm{O}(3.8 \%)$ contacts. By contrast, as $\mathrm{Cl} 2$ anion was surrounded by pairs of water and cation molecules through $\mathrm{O}-\mathrm{H} \cdots \mathrm{Cl} 2$ and $\mathrm{N}-\mathrm{H} \cdots \mathrm{Cl} 2$ hydrogen bonds, the $\mathrm{H} \cdots \mathrm{Cl} / \mathrm{Cl} \cdots \mathrm{H}$ contacts saturate the entire Hirshfeld surface about the $\mathrm{Cl} 2$ anion.

Tab. 8: Percentage contributions of inter-atomic contacts to the Hirshfeld surface.

\begin{tabular}{|c|c|c|c|c|c|}
\hline Contact & water & $\mathrm{C} 11$ & $\mathrm{Cl} 2$ & cation a & cation $b$ \\
\hline $\mathrm{H} \cdots \mathrm{H}$ & 50.3 & - & - & 52.5 & 52.2 \\
\hline $\mathrm{H} \cdots \mathrm{O} / \mathrm{O} \cdots \mathrm{H}$ & 30.8 & - & - & 21.9 & 17.2 \\
\hline $\mathrm{H} \cdots \mathrm{Cl} / \mathrm{Cl} \cdots \mathrm{H}$ & 18.9 & 75.6 & 100 & 8.2 & 12.8 \\
\hline $\mathrm{H} \cdots \mathrm{N} / \mathrm{N} \cdots \mathrm{H}$ & - & - & - & 6.4 & 5.9 \\
\hline $\mathrm{C} \cdots \mathrm{Cl} / \mathrm{Cl} \cdots \mathrm{C}$ & - & 13.3 & - & 1.9 & 1.9 \\
\hline $\mathrm{O} \cdots \mathrm{C} / \mathrm{C} \cdots \mathrm{O}$ & - & - & - & 2.2 & 1.9 \\
\hline $\mathrm{H} \cdots \mathrm{C} / \mathrm{C} \cdots \mathrm{H}$ & - & - & - & 2.1 & 3.2 \\
\hline $\mathrm{O} \cdots \mathrm{N} / \mathrm{N} \cdots \mathrm{O}$ & - & - & - & 1.9 & 2.9 \\
\hline $\mathrm{C} \cdots \mathrm{N} / \mathrm{N} \cdots \mathrm{C}$ & - & - & - & 1.3 & 0.6 \\
\hline $\mathrm{N} \cdots \mathrm{Cl} / \mathrm{Cl} \cdots \mathrm{N}$ & - & 7.3 & - & 1.0 & 1.1 \\
\hline $\mathrm{O} \cdots \mathrm{Cl} / \mathrm{Cl} \cdots \mathrm{O}$ & - & 3.8 & - & 0.5 & 0.3 \\
\hline $\mathrm{O} \cdots \mathrm{O}$ & - & - & - & 0.1 & - \\
\hline
\end{tabular}


Although both cations participate in similar intermolecular interactions and exhibit comparable two-dimensional fingerprint plots, Figure 11, the percentages for the delineated contacts are distinct, at least for some specific contacts, Table 8 . The most significant intermolecular contacts for both cations are the $\mathrm{H} \cdots \mathrm{H}$ contacts and these appeared as a beaklike distribution tipped at $d_{\mathrm{e}}=d_{\mathrm{i}} \sim 2.0 \AA$. The $\mathrm{H} \cdots \mathrm{H}$ contacts contributed 52.5 and $52.2 \%$ to the overall Hirshfeld surfaces of cations a and b, respectively. The next most significant contacts to the respective surfaces present a clear differentiation [35] between the cations, namely 21.9 and $17.2 \%$ for $\mathrm{H} \cdots \mathrm{O} / \mathrm{O} \cdots \mathrm{H}$ contacts. Consistent with the $\mathrm{N}-\mathrm{H} \cdots \mathrm{Cl}$ interactions in the crystal, $\mathrm{H} \cdots \mathrm{Cl} / \mathrm{Cl} \cdots \mathrm{H}$ contacts were observed as a single shape peak at $d_{\mathrm{e}}+d_{\mathrm{i}} \sim 2.2 \AA$, Figure 11 , and contributed differentially for cations a $(8.2 \%)$ and $\mathrm{b}(12.8 \%)$. Both $\mathrm{H} \cdots \mathrm{N} / \mathrm{N} \cdots \mathrm{H}$ and $\mathrm{C} \cdots \mathrm{Cl} / \mathrm{Cl} \cdots \mathrm{C}$ contacts appear at $\mathrm{d}_{\mathrm{e}}+\mathrm{d}_{\mathrm{i}} \sim 2.8-3.6 \AA$ in the respective fingerprint plots, but their contribution to the Hirshfeld surface are only $6.4-1.9 \%$. The contribution from the other interatomic contacts summarised in Table 8 seemingly have minor influences upon the Hirshfeld surfaces in $\mathbf{1}$, as their individual contribution are less than $4 \%$.

\section{Molecular electrostatic mapping}

Cation a, the $\mathrm{Cll}$ anion and the water molecule were subjected to molecular electrostatic mapping (MEP) using the same basis set and level of theory indicated above to comprehend the charge distribution for these fundamental components of $\mathbf{1}$, so as to correlate with the interactions present in the crystal; the outputs were analysed and interpreted through GaussView6 [36]. The results for cation b and the $\mathrm{Cl} 2$ anion were indistinguishable for those obtained for cation a and $\mathrm{Cl1}$ and hence, are not discussed herein. The MEP study shows the carbamate cation to be predominantly electrostatically positive in nature with the maximum electrostatic potential (blue) mostly residing on the amide protons which correlates well with their nature as hydrogen bond donors, Figure 12. Among all atoms present in the cation, the 
carbonyl oxygen has relatively less positive electrostatic potential charge which is consistent with its nature as hydrogen bond acceptor. On the other hand, the chloride anion exhibits a homogeneous negative electrostatic potential surrounding the atom corresponding to the strong nucleophilic characteristics. A similar feature is observed for the oxygen atom in the water molecule. The MEP results are consistent with the interaction patterns identified through the experimental study in which the interactions occur owing charge complementary electrostatic attractions between the hydrogen bond donors and acceptors.
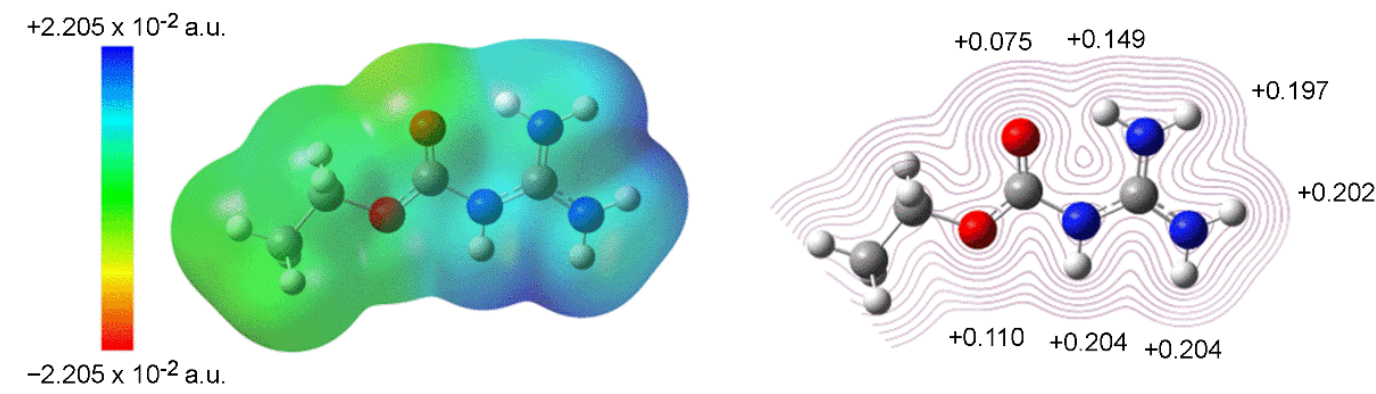

(a)

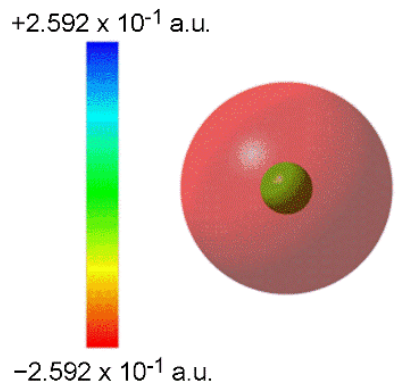

(b)
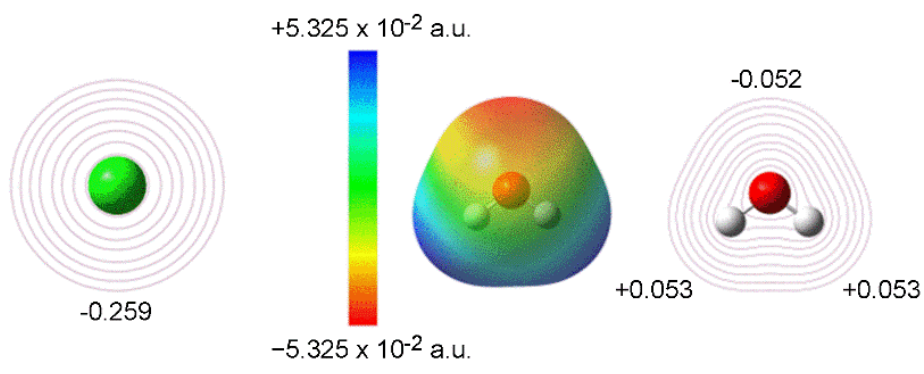

(c)

Figure 12. MEP map and two-dimensional contour plot (iso-density $=0.004$ a.u.) for (a) cation a, (b) the Cl1 anion and (c) the water molecule, showing the electrostatic potential charge on selected atoms.

\section{Calculation of interaction energies}

For interaction energy calculations, the studies were conducted using the long-range corrected wB97XD density functional with Grimme's D2 dispersion model [37] and Ahlrichs's valence 
triple-zeta polarization basis sets, wB97XD/def2-tzvpp [38, 39]. The long-range corrected hybrid model has been shown to greatly reduce self-interaction errors and to give better accuracy in the interaction energies [40]. Basis set superposition error (BSSE) on the calculated energies was corrected by counterpoise correction [41, 42].

The interaction energies for interactions identified through the crystallographic study are collated in Table 9. Among all intermolecular contacts, the charge-assisted $\mathrm{N}-\mathrm{H} \cdots \mathrm{Cl}$ interactions exhibit the greatest strength with the maximum counterpoise corrected energy, $E_{\text {int }}^{\mathrm{BSSE}}$, being $-98.00 \mathrm{kcal} / \mathrm{mol}$. While the calculated energy is much stronger than typical hydrogen bonds, the data is in accord to the reported value of $-106 \mathrm{kcal} / \mathrm{mol}$ for a comparable charge-assisted $\mathrm{C}(=\mathrm{O})-\mathrm{N}-\mathrm{H} \cdots \mathrm{Cl}$ interaction obtained by DFT-B3LYP/6-31+G(d,p) [43]. On the other hand, water-O- $\mathrm{H} \cdots \mathrm{Cl}$ interaction exhibits a relatively smaller $E_{\text {int }}^{\mathrm{BSSE}}$ of about -14 $\mathrm{kcal} / \mathrm{mol}$.

Tab. 9: The summary of interaction energies calculated for interactions occurring in $\mathbf{1}$.

$\begin{array}{lll}\text { Interaction } & \begin{array}{l}\text { Interaction energy, } \\ E_{\text {int }}^{\mathrm{BSSE}}(\mathrm{kcal} / \mathrm{mol})\end{array} & \begin{array}{l}\text { Symmetry } \\ \text { operation }\end{array} \\ \mathrm{N} 1 \mathrm{a}-\mathrm{H} 1 \mathrm{n} \cdots \mathrm{O} 1 \mathrm{w} & -7.92 & x, y, z \\ \mathrm{~N} 1 \mathrm{a}-\mathrm{H} 2 \mathrm{n} \cdots \mathrm{O} 1 \mathrm{a} & 35.35 & -x, 1-y, 1-z \\ \mathrm{~N} 2 \mathrm{a}-\mathrm{H} 3 \mathrm{n} \cdots \mathrm{Cl} 2 & x, y, z \\ \mathrm{~N} 2 \mathrm{a}-\mathrm{H} 4 \mathrm{n} \cdots \mathrm{Cl1}+ & -96.94 & \\ \mathrm{~N} 3 \mathrm{a}-\mathrm{H} 5 \mathrm{n} \cdots \mathrm{Cl1} & & x, y, z \\ \mathrm{~N} 1 \mathrm{~b}-\mathrm{H} 6 \mathrm{n} \cdots \mathrm{Cl} 2 & -112.31 & -1+x, 1+y, z \\ \mathrm{~N} 1 \mathrm{~b}-\mathrm{H} 7 \mathrm{n} \cdots \mathrm{O} 1 \mathrm{~b} & -98.00 & -x, 2-y,-z \\ \mathrm{~N} 2 \mathrm{~b}-\mathrm{H} 8 \mathrm{n} \cdots \mathrm{O} 1 \mathrm{w} & 36.02 & x, 1+y, z\end{array}$




$\begin{array}{lll}\mathrm{N} 2 \mathrm{~b}-\mathrm{H} 9 \mathrm{n} \cdots \mathrm{Cl1}+ & \\ \mathrm{N} 3 \mathrm{~b}-\mathrm{H} 10 \mathrm{n} \cdots \mathrm{C} 11 & -112.20 & -1+x, y, z \\ \mathrm{O} 1 \mathrm{w}-\mathrm{H} 10 \cdots \mathrm{Cl} 2 & -14.01 & x, y, z \\ \mathrm{O} 1 \mathrm{w}-\mathrm{H} 2 \mathrm{o} \cdots \mathrm{Cl} 2 & -14.05 & -1+x, y, z \\ \mathrm{C} 4 \mathrm{~b}-\mathrm{H} 4 \mathrm{~b} 3 \cdots \mathrm{O} 2 \mathrm{~b} & 52.41 & x, y, z \\ \mathrm{C} 4 \mathrm{a}-\mathrm{H} 4 \mathrm{a} 1 \cdots \mathrm{O} 1 \mathrm{w} & -3.56 & \\ \mathrm{C} 1 \mathrm{a} \cdots \mathrm{O} 1 \mathrm{a}+ & & 1-x, 1-y, 1-z \\ \mathrm{C} 2 \mathrm{a} \cdots \mathrm{N} 1 \mathrm{a} & & \end{array}$

To assess the reliability and accuracy of the calculated data obtained from DFTwB97XD/def2-tzvpp, the $\mathrm{O}-\mathrm{H} \cdots \mathrm{Cl}$ interaction was subjected to second order Møller-Plesset energy calculation $[44,45]$ combined with Dunning's triple-zeta correlation consistent basis set augmented with diffuse functions (MP2/aug-cc-pvtz) [46, 47] as well as coupled cluster calculation by including non-iterative triple excitations $[48,49]$ and with the aug-cc-pvtz basis set, $\operatorname{CCSD}(\mathrm{t}) /$ aug-cc-pvtz. The MP2 and $\operatorname{CCSD}(\mathrm{t})$ calculations show that $E_{\text {int }}^{\mathrm{BSSE}}(\mathrm{O}-\mathrm{H} \cdots \mathrm{Cl})$ is about -13.24 and $-13.10 \mathrm{kcal} / \mathrm{mol}$, respectively. Although these methods of calculation were not applied for $\mathrm{N}-\mathrm{H} \cdots \mathrm{Cl}$ due to the computational cost involved for these relatively larger interacting molecules, the data obtained by the DFT approach should be deemed reliable judging by the concordance of the results with deviations of about $1 \mathrm{kcal} / \mathrm{mol}$ compared to the benchmark approach. The large difference in $E_{\text {int }}^{\mathrm{BSSE}}$ for the $\mathrm{N}-\mathrm{H} \cdots \mathrm{Cl}$ and $\mathrm{O}-\mathrm{H} \cdots \mathrm{Cl}$ interactions could be due to the former interaction involving two charged/semi-charged species.

The interactions between carbamate cations, for example, N1a-H2n $\cdots \mathrm{O} 1 \mathrm{a}, \mathrm{N} 1 \mathrm{~b}-$ $\mathrm{H} 7 \mathrm{n} \cdots \mathrm{O} 1 \mathrm{~b}, \mathrm{C} 4 \mathrm{~b}-\mathrm{H} 4 \mathrm{~b} 3 \cdots \mathrm{O} 2 \mathrm{~b}$ and $\mathrm{C} 1 \mathrm{a} \cdots \mathrm{O} 1 \mathrm{a} / \mathrm{C} 2 \mathrm{a} \cdots \mathrm{N} 1 \mathrm{a}$ interactions, result in positive $E_{\text {int }}^{\mathrm{BSSE}}$ 
values consistent with expectation due to the high repulsion energy from the like-charged molecular species.

\section{Conclusions}

Crystallography on $\mathbf{1}$ shows the independent cations to exhibit extensive delocalisation of the positive over the $\mathrm{CN}_{3}$ atoms, especially involving the terminal nitrogen atoms. A conformational difference in the terminal ethyl groups is ascribed to molecular packing effects. Hydrogen-bonding dominates, often charge-assisted, the packing in the crystals and this is confirmed by the charge distribution for the constituent species noted through the calculated molecular electrostatic potentials. The calculated interaction energies for $\mathrm{N}-\mathrm{H} \cdots \mathrm{Cl}$ are greater than for water-O- $\mathrm{H}^{\cdots} \mathrm{Cl}$. In summary, the complementary experimental/computational approach undertaken herein rationalises observed differences in the crystallographic structures and provides an explanation for the arrangement of the constituent species in the crystal. 


\section{References}

1 Nencki, M. Über die guanidinderivate. Ber. Dtsch. Chem. Ges. 1874, 7, 1584-1593.

2 Basterfield, S., Paynter, L. E. Studies in urethans I. Mono- and dicarbethoxyguanidines; dicarbethoxy-ethyl-iso-urea. J. Am. Chem. Soc. 1926, 48, 2176-2179.

3 Kawano, K., Odo, K. Synthesis of guanyl-O-alkylisourea and its reactions. Nippon Kagaku Zasshi, 1961, 82, 1672-1675.

4 Tahir, M. N., Muir, C., Danish, M., Tariq, M. I., Ülkü, D.

Bis[diamino(ethoxycarbonylamino)methylium] sulfate. Acta Crystallogr., Sect. E: Struct. Rep. Online, 2009, 65, o785.

5 Groom, C. R., Bruno, I. J., Lightfoot, M. P., Ward, S. C. The Cambridge Structural Database. Acta Crystallogr. B Struct. Sci. Cryst. Eng. Mater. 2016, 72, 171-179.

6 Scheindlin, S. Episodes in the story of physostigmine. Mol. Interv. 2010, 10, 4-10.

7 Gupta, R. C. Toxicology of Organophosphate and Carbamate Compounds; Academic Press: London, 2006.

8 Selva, M., Tundo, P., Perosa, A. The synthesis of alkyl carbamates from primary aliphatic amines and dialkyl carbonates in supercritical carbon dioxide. Tetrahedron Lett. 2002, 43, 1217-1219.

9 Ghosh, A. K., Brindisi, M. Organic carbamates in drug design and medicinal chemistry. J. Med. Chem. 2015, 58, 2895-2940.

10 Woodard \& Curran, Inc. Methods for Treating Wastewaters from Industry. In Industrial Waste Treatment Handbook; $2^{\text {nd }}$ Edition; Woodard \& Curran, Inc., Eds. ButterworthHeinemann: Burlington, 2006; pp. 149-334.

11 Weber, J. V., Sharypov, V. I. Ethyl carbamate in foods and beverages: a review. Environ. Chem. Lett. 2009, 7, 233-247. 
12 Jäger, P., Rentzea, C. N., Kieczka, H. Carbamates and Carbamoyl Chlorides. In Ullmann's Encyclopedia of Industrial Chemistry; Wiley-VCH: Weinheim, 2011; pp. $149-334$.

13 Pinner, A., Klein, F. Umwandlung der Nitrile in Imide. Ber. Dtsch. Chem. Ges. 1878, $10,1889-1897$.

14 Pfaff, D., Nemecek, G., Podlech, J. A. Lewis acid-promoted Pinner reaction. Beilstein J. Org. Chem. 2013, 9, 1572-1577.

15 Pfaff, D., Nemecek, G., Podlech, J. A. Hydrogen chloride-free Pinner reaction promoted by Lewis acids. Helv. Chim. Acta, 2012, 95, 1851-1856.

16 SAINT \& SADABS, Bruker: Madison, WI, USA, 2012.

17 Sheldrick, G. M. A short history of SHELX, Acta Crystallogr. A, Found. Cryst. 2008, $64112-122$.

18 Sheldrick, G. M. Crystal structure refinement with SHELXL, Acta Crystallogr. C, Struct. Chem. 2015, 71, 3-8.

19 Farrugia, L. J. WinGX and ORTEP for Windows: an update, J. Appl. Crystallogr. 2012, $45,849-854$.

20 Brandenburg, K. DIAMOND. Crystal Impact GbR: Bonn, Germany, 2006.

21 Spek, A. L. checkCIF validation ALERTS: what they mean and how to respond. Acta Crystallogr. Sect. E: Crystallogr. Commun. 2020, 76, 1-11.

22 Frisch, M. J., Trucks, G. W., Schlegel, H. B., Scuseria, G. E., Robb, M. A., Cheeseman, J. R., Scalmani, G., Barone, V., Mennucci, B., Petersson, G. A., Nakatsuji, H., Caricato, M., Li, X., Hratchian, H. P., Izmaylov, A. F., Bloino, J., Zheng, G., Sonnenberg, J. L., Hada, M., Ehara, M., Toyota, K., Fukuda, R., Hasegawa, J., Ishida, M., Nakajima, T., Honda, Y., Kitao, O., Nakai, H., Vreven, T., Montgomery, J. A., Peralta, Jr., J. E., Ogliaro, F., Bearpark, M., Heyd, J. J., Brothers, E., Kudin, K. N., Staroverov, V. N., 
Kobayashi, R., Normand, J., Raghavachari, K., Rendell, A., Burant, J. C., Iyengar, S. S., Tomasi, J., Cossi, M., Rega, N., Millam, J. M., Klene, M., Knox, J. E., Cross, J. B., Bakken, V., Adamo, C., Jaramillo, J., Gomperts, R., Stratmann, R. E., Yazyev, O., Austin, A. J., Cammi, R., Pomelli, C., Ochterski, J. W., Martin, R. L., Morokuma, K., Zakrzewski, V. G., Voth, G. A., Salvador, P., Dannenberg, J. J., Dapprich, S., Daniels, A. D., Farkas, Ö., Foresman, J. B., Ortiz, J. V., Cioslowski, J., Fox, D. J. Gaussian 16, Revision C.01; Gaussian Inc.: Wallingford, Connecticut, USA, 2016.

23 Roothaan, C. C. J. New developments in molecular orbital theory. Rev. Mod. Phys. $1951,23,69-89$.

24 Binkley, J. S., Pople, J. A., Hehre, W. J. Self-consistent molecular orbital methods. 21. Small split-valence basis sets for first-row elements. J. Am. Chem. Soc. 1980, 102, 939947.

25 Becke, A. D. Density-functional thermochemistry. III. The role of exact exchange. $J$. Chem. Phys. 1993, 98, 5648-5652.

26 McLean, A. D., Chandler, G. S. Contracted Gaussian-basis sets for molecular calculations. 1. 2nd row atoms, $\mathrm{Z}=11-18$. J. Chem. Phys. 1980, 72, 5639-5648.

27 Raghavachari, K., Binkley, J. S., Seeger, R., Pople, J. A. Self-consistent molecular orbital methods. 20. Basis set for correlated wave-functions. J. Chem. Phys. 1980, 72, $650-654$.

28 Glendening, E. D., Reed, A. E., Carpenter, J. E., Weinhold, F. NBO Version 3.1; Theoretical Chemistry Institute: University of Wisconsin, Madison, USA, 1998.

29 Reed, A. E., Curtiss, L. A., Weinhold, F. Intermolecular interactions from a natural bond orbital, donor-acceptor viewpoint. Chem. Rev., 1988, 88, 899-926.

30 Spackman, M. A., Jayatilaka, D. Hirshfeld surface analysis. CrystEngComm, 2009, 11, $19-32$. 
31 Spackman, M. A., McKinnon, J. J. Fingerprinting intermolecular interactions in molecular crystals. CrystEngComm, 2002, 4, 378-392.

32 Turner, M. J., McKinnon, J. J., Wolff, S. K., Grimwood, D. J., Spackman, P. R., Jayatilaka, D., Spackman, M.A. CrystalExplorer, Version 17.5; University of Western Australia: Western Australia, Australia, 2017.

33 Tan, S. L., Jotani, M. M., Tiekink, E. R. T. Utilizing Hirshfeld surface calculations, non-covalent interaction (NCI) plots and the calculation of interaction energies in the analysis of molecular packing, Acta Crystallogr., Sect. E: Struct. Rep. Online, 2019, $75,308-318$.

34 Spackman, M. A., McKinnon, J. J., Jayatilaka, D. Electrostatic potentials mapped on Hirshfeld surfaces provide direct insight into intermolecular interactions in crystals. CrystEngComm, 2008, 10, 377-388.

35 Jotani, M. M., Wardell, J. L., Tiekink, E. R. T. Supramolecular association in the triclinic $\left(Z^{\prime}=1\right)$ and monoclinic $\left(Z^{\prime}=4\right)$ polymorphs of 4-(4-acetylphenyl)piperazin-1ium 2-amino-4-nitrobenzoate. Z. Kristallogr. - Cryst. Mater. 2019, 234, 43-57.

36 Dennington, R., Keith, T. A., Millam, J. M. GaussView, Version 6; Semichem Inc., Shawnee Mission: Kansas, USA, 2016.

37 Chai, J. D., Head-Gordon, M. Long-range corrected hybrid density functionals with damped atom-atom dispersion corrections. Phys. Chem. Chem. Phys. 2008, 10, 66156620.

38 Weigend, F., Ahlrichs, R. Balanced basis sets of split-valence, triple zeta valence and quadruple zeta valence quality for H to Rn: Design and assessment of accuracy. Phys. Chem. Chem. Phys. 2005, 7, 3297-3305.

39 Weigend, F. Accurate Coulomb-fitting basis sets for H to Rn. Phys. Chem. Chem. Phys. $2006,8,1057-1065$. 
40 Andersen, C. L., Jensen, C. S., Mackeprang, K., Du, L., Jørgensen, S., Kjaergaard, H. G. Similar strength of the $\mathrm{NH} \cdots \mathrm{O}$ and $\mathrm{NH}^{\cdots} \mathrm{S}$ hydrogen bonds in binary complexes. $J$. Phys. Chem. A, 2014, 118, 11074-11082.

41 Boys, S. F., Bernardi, F. The calculation of small molecular interactions by differences of separate total energies - some procedures with reduced errors. Mol. Phys. 1970, 19, $553-566$.

42 Simon, S., Duran, M., Dannenberg, J. J. How does basis set superposition error change the potential surfaces for hydrogen bonded dimers? J. Chem. Phys. 1996, 105, $11024-11031$.

43 Defazio, S., Tamasi, G., Cini, R. A molecular orbital study of C- $\mathrm{H}^{\cdots} \mathrm{Cl}^{-}$and $\mathrm{N}-\mathrm{H}^{\cdots} \mathrm{Cl}^{-}$ hydrogen bonds. Inferences on selected metal complexes and on protein $\mathrm{ClC}^{-}$ channels. C. R. Chim. 2005, 8, 1584-1609.

44 Frisch, M. J., Head-Gordon, M., Pople, J. A. Semi-direct algorithms for the MP2 energy and gradient. Chem. Phys. Lett. 1990, 166, 281-289.

45 Head-Gordon, M., Pople, J. A., Frisch, M. J. MP2 energy evaluation by direct methods. Chem. Phys. Lett. 1988, 153, 503-506.

46 Dunning Jr., T. H. Gaussian basis sets for use in correlated molecular calculations. I. The atoms boron through neon and hydrogen. J. Chem. Phys. 1989, 90, 1007-1023.

47 Woon, D. E., Dunning Jr., T. H. Gaussian-basis sets for use in correlated molecular calculations. 3. The atoms aluminum through argon, J. Chem. Phys. 1993, 98, 13581371.

48 Purvis III, G. D., Bartlett, R. J. A full coupled-cluster singles and doubles model - the inclusion of disconnected triples. J. Chem. Phys. 1982, 76, 1910-1918. 
49 Pople, J. A., Head-Gordon, M., Raghavachari, K. Quadratic configuration interaction a general technique for determining electron correlation energies. J. Chem. Phys. 1987, $87,5968-5975$. 